\title{
Reconstructing ancient architecture at Tiwanaku, Bolivia: the potential and promise of $3 \mathrm{D}$ printing
}

\author{
Alexei Vranich * (1)
}

\begin{abstract}
The ruins of Tiwanaku (A.D. 500-950), in the modern republic of Bolivia, present an archaeological challenge owing to intense looting during the colonial period that effectively demolished the site. One building in particular, known as the Pumapunku, was described by Spanish conquistadors and travelers of the sixteenth and seventeenth centuries, as a wondrous, though unfinished, building with gateways and windows carved from single blocks. Unparalleled in the pre-Colombian New World, the craftsmanship of this masonry has long been considered the architectural apogee of Andean pre-Colombian lithic technology. Unfortunately, during the last 500 years, treasure hunters have ransacked this building to the point that none of approximately shattered remains of 150 blocks of the standing architecture are to be found in their original place. Over the last century and a half, several different scholars have carefully measured the shattered architecture and even managed to join several fragments to form complete pieces. This research revisited these historic field notes with a view to transforming this century and a half of documentation into solid 3D form. These measurements were entered by hand into an architectural modeling program; the virtual form was subsequently printed in 3D form at 4\% reduced scale. Unlike large architectural pieces - or notes or models on a computer screen-3D-printed pieces can be manipulated quickly and intuitively, allowing researchers to try combinations and seek connections rapidly, turning over pieces and testing possible fits. This tactile engagement, along with the ability to quickly try out combinations of the 3D-printed pieces, led to fresh and often unexpected insights. Once refined and simplified, this methodology, was demonstrated to the indigenous site managers who were provided with a full copy of the printed architectural fragments with a view to continuing research and to present the work to visitors, stakeholders and other scholars.
\end{abstract}

Keywords: 3D printing, Rapid prototyping, Architecture, Archaeology, Andes, Bolivia, Tiwanaku, Masonry, Megaliths

\section{Background}

This effort represents a technological step back from recent efforts in the virtual assembly of fragmentary data through the use of advanced computer programing, and instead denotes an attempt to capitalize on the archaeologist's learned ability to visualize and mentally rotate irregular objects in 3D space. The case study is the highly damaged pre-Colombian monument in the high Andes of Bolivia known as the Pumapunku (Gateway of the Puma or Jaguar). The most common word used in

*Correspondence: avranich@gmail.com

Archaeological Research Facility, University of California, 2251 College Building, Berkeley, CA 94720, USA the description of this complex ruin is "inconceivable" - a word penned in the first description of the site in 1549 [1], and that continues to be used in popular literature and by tour guides today. The intent of the project, then, was to translate the inconceivable into the conceivable, or in more precise terms, to translate the complex and cumbersome data that is difficult to visualize and test into something that both our hands and our minds could grasp. Unlike pottery or bone artifacts, which archaeologists are accustomed to handling and refitting due to their smaller size, the majority of the blocks were too large to move. To overcome this challenge, the project team tested a variety of field-recording techniques, 


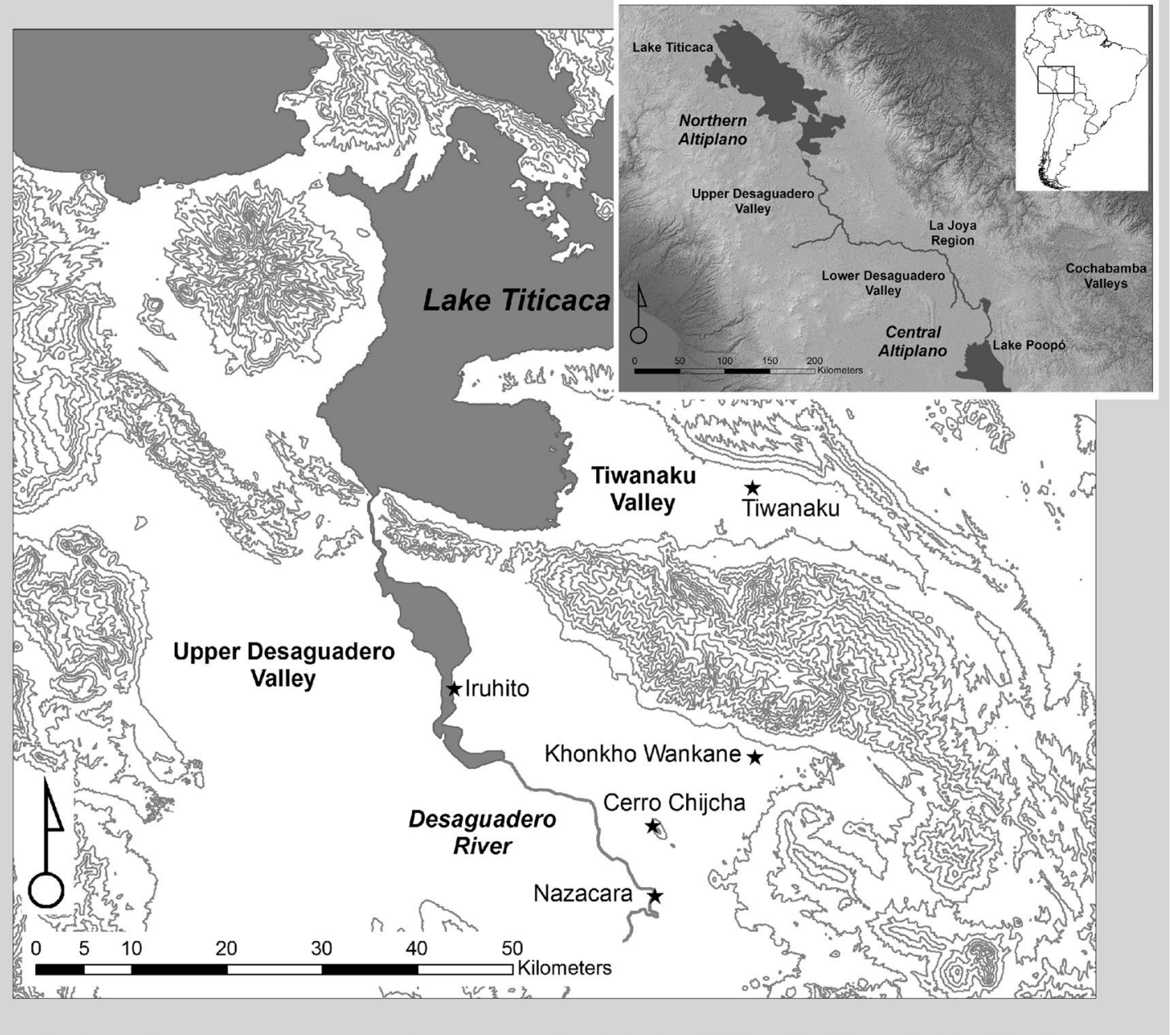

Fig. 1 Titicaca basin and the major archaeological sites

eventually relying almost exclusively on an extensive set of archival field records from various scholars to manually input and create virtual 3D models of architectural fragments. Thereafter, the project used additive manufacturing, more commonly known as 3D printing, to create reduced and accurate models of the fragments. Having the pieces all visible and immediately accessible resulted in an engaging and non-stop process of trial and error and moments of insight that could be quickly tested on the models. Due to the quantity of ashlars that has been lost or remains unexcavated, a full reconstruction of this building is unlikely, at least for the moment; nevertheless, this research reconstructs enough of the building to understand the form of the building. Those interpretations are beyond the scope of the paper; in their place, for this publication we focus on the manner in which we can revalue previous fieldwork from the last century and created a novel, effective and non-invasive methodology of reconstructing shattered architecture that can be comprehensible to a wide range of stakeholders.

\section{Setting}

Similar to the Nile River and the Indus Valley, the Titicaca basin holds the distinctions of being one of the few places on earth where civilization arose sui generis. The earliest example of public ritual architecture in the Titicaca basin, the sunken court, dates to 1800 B.C. [2, 3]. This hallmark of Titicaca architecture comes to an end around A.D. 1000, by which time an estimated 800 sunken courts had been built throughout the basin. At the site of Chiripa (550 B.C. to A.D. 100) and Pucara (200 B.C. -A.D. 300) - two of the larger and better-known sites before the Tiwanaku phenomenon-the sunken 


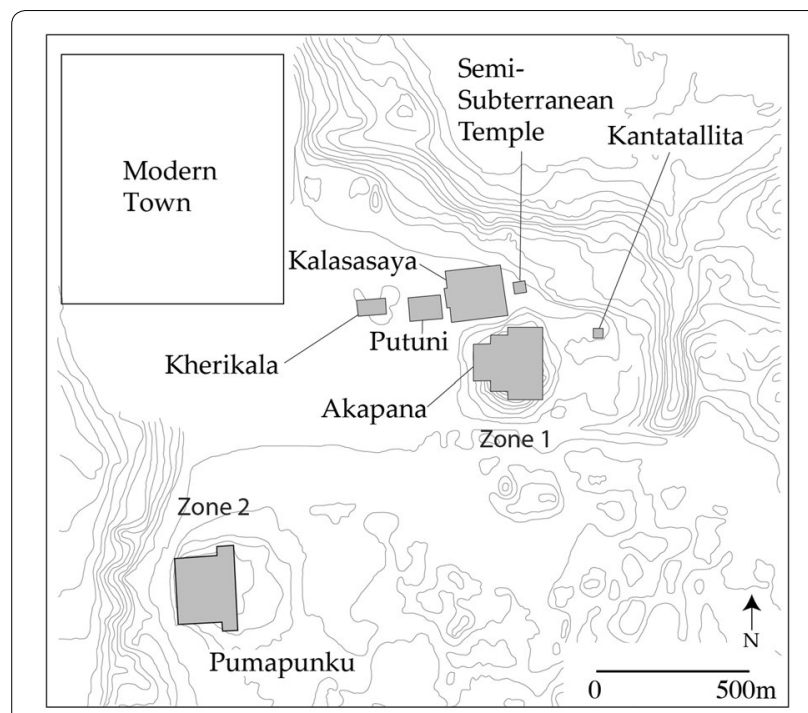

Fig. 2 The primary monuments of the site of Tiwanaku

courts are surrounded by internally complex rectilinear buildings, or "houses" made of earth (adobe) and stone.

In the approximate center of the southern valley of the basin lies a series of pyramids and platforms that marks the center of the ruins of Tiwanaku, occupied ca. A.D. 500-1000 (Fig. 1). Descriptions of monumental Tiwanaku focus on two zones located east and southwest of the modern town of Tiwanaku (Fig. 2). To the east sits the main core of seven stone and earth structures: the Semi-subterranean Temple, the Kalasasaya, the Putuni, the Chunchukala, the Kherikala, the Kantatallita, and the Akapana Platform (Zone 1). To the southwest lies the subject of this study, the Pumapunku, an alignment of plazas and ramps centered on a raised platform (Zone 2). The ruins challenge investigators owing both to modifications by the later mature polity, harsh weather, and the intense colonial period looting that destroyed all but the largest of features.

The ruins have played a major role in historic and mythic narratives of the various states and empires that have controlled the area [4]. The Inca repurposed the ruins as their place of birth; the Spanish assiduously went about destroying it; the developing mestizo classes that it was indeed built by the Inca Emperor attempting to recreate Jerusalem [5]. During the wars of independence from Spain, the famed Gateway of the Sun was reset in a standing position to mark the start of a new order. After independence, the ruins appeared as part of the tug of war between the two major cities-La Paz and Sucrevying for the ideological justification to serve as the seat of the newly formed republic of Bolivia.
In the mid-twentieth century, an ambitious effort was started to create an impressive set of ruins that would rival Machu Picchu in Peru, and Teotihuacan in Mexico [6]. Any monumental site across the basin, and even across the southern Andes, was assigned as a satellite or outpost city of an imagined Tiwanaku empire [7]. At the ruins themselves, an extensive program of excavations and heavy-handed restorations transformed the picturesque vestiges of eroded stone into its present overreconstructed state. Entire sections of architecture were removed and reset to give the site a more monumental feel in line with the nationalist narrative of a pre-Columbian empire of similar proportions and size to the later Inca Empire [4]. As a result of these unfortunate interventions, the ruins also hold the distinction of being considered one of the worst reconstructed sites in the continent [8]. Nevertheless, the ruins became an obligatory visit by international travelers and indigenous and mestizo nationals, each who brought their own agenda and interpretation [9]. In particular, the solstice festival, restarted in the 1980s after a short period of revival in the mid-twentieth century, brought the ruins international attention, and local interest as the local indigenous peoples used the ceremony both as source of income, and identity. The festival developed from a small gathering into a well-organized event hosting thousands, and could be argued that the election of the first indigenous president-and his inauguration at the ruins themselveswere made possible by the yearly gathering what would become his solid political base [10].

This period of politically driven rushed excavations and heavy-handed restorations has, for the most part, come to an end, but the situation at the ruins remains just as complicated with the decentralization of power from the central government to the regions and provinces. In 2001, the indigenous communities took over the ruins and expelled all the central government workers [11]. Over time, relations have improved and there is a higher degree of collaboration between the indigenous rural authorities and national and international organizations. Nevertheless, the majority of the stakeholders at the site are not archaeologists or academics, but those who occupy a range of traditional, local, and national political positions. As well intended as they may be, this diverse group of stakeholders has a limited understanding of the conventions of conservation and proper management of a World Heritage Site. Even under the best of circumstances, academic publications and thick government conservation reports have little impact on the debate of how to preserve, restore, and maintain the site, and discussions between the stakeholders rarely find common language. For example, in 2006, the stones of the Pumapunku were rearranged as part of a project ordered by 


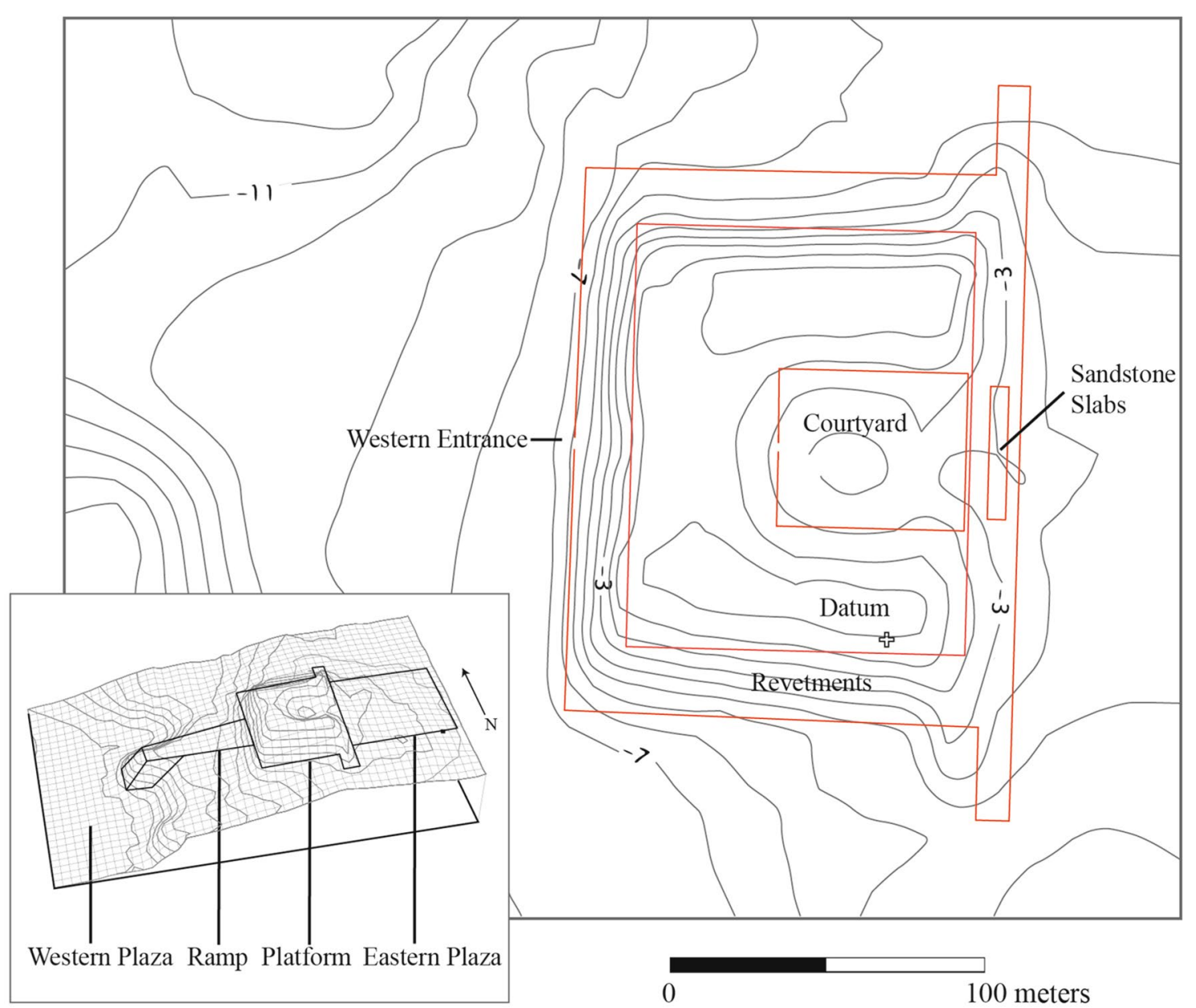

Fig. 3 Topographic and plan view of the Pumapunku

the interim president of the country to "fix" the site during his short tenure. The large sandstone slabs were leveled and several blocks were reset, but both their location and arrangement are incorrect according to easily accessible publications [12].

\section{The Pumapunku}

The first known plan-view of the temple complex, made in 1848 by Léonce Angrand, places fragmentary remains of four concentric revetments around a raised platform [13]. Beginning in the mid 1970s, a series of excavations confirmed the remains of these concentric revetments of true horizontal coursing [14], along with a wide, worn set of sandstone stairs on the west side [15-17]. The footprint of the platform is T-shaped, extending $167 \mathrm{~m}$ along the west side, and $116 \mathrm{~m}$ along the north and south sides. The wings of the " $T$ " extend out $27 \mathrm{~m}$ and are estimated to be $20 \mathrm{~m}$ wide $[18,19]$ (Fig. 3). The partially dismantled exterior revetments of the platform attest to the sides and the base of the ashlars being completely finished before being set in their respective courses. Fitting perfectly front to back, the entire course was ground down to form a continuous flat, true horizontal course.

This research focuses on the east side of the platform, an alignment of large sandstone slabs surrounded by a tumble of intricately carved andesite blocks (Fig. 4). Astonished by this impressive collection of shattered and overturned architecture, several Spanish chroniclers of the sixteenth and seventeenth centuries left us with descriptions of wondrous, though unfinished, gateways and other interesting carved blocks that sat upon and around cyclopean sandstone stone slabs [1, 20,21]. Architectural studies have confirmed the early observation that both the andesite architecture and sandstone slabs were unfinished [1, 12, 20, 22-25]. By the early 1600 s, it appears that only one gateway and a "window" remained in place, and these may have remained standing until the mid-1700s. For the most part, the early 


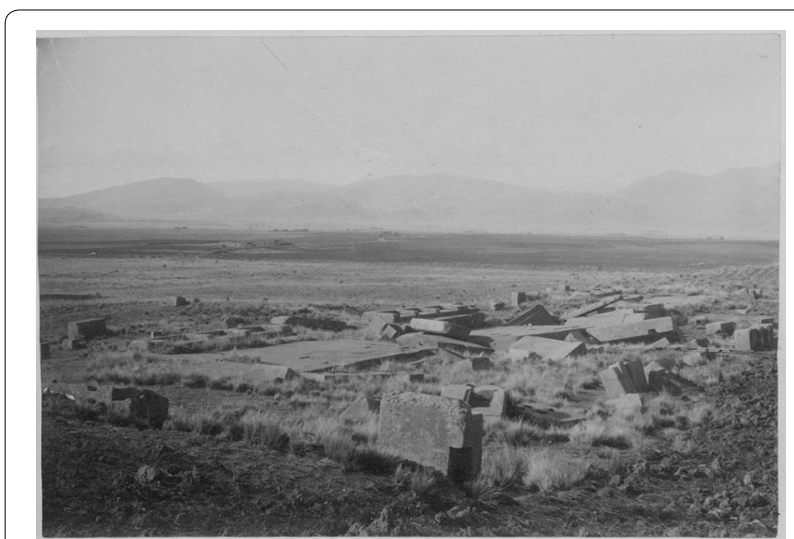

Fig. 4 Historic photograph of the architecture on the east side of the Pumapunku platform taken by Max Uhle in 1893

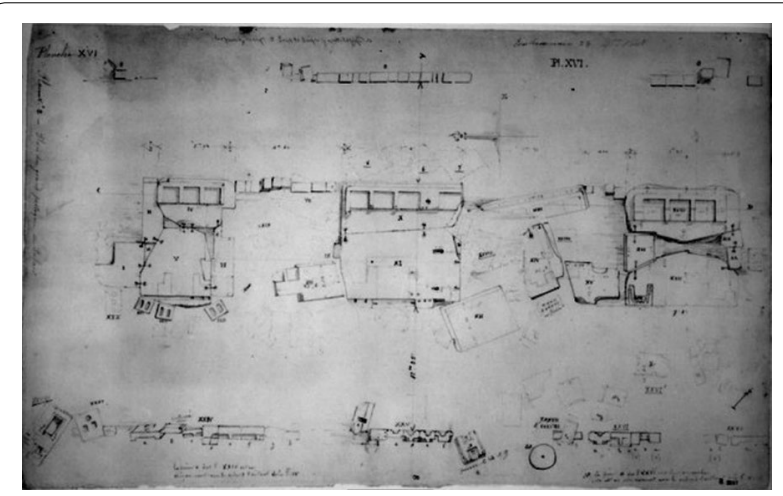

Fig. 5 Drawing from 1848 by Leonce Angrand of the sandstone slabs. Notice the geometric outlines carved into the slabs that once held standing architecture

colonial descriptions prior to the complete destruction of the standing andesite architecture convey a sense of awe rather than a specific architectural form; later descriptions provide a few additional insights - and a great deal of speculation-on what is by the nineteenth century a heavily damaged structure [26-30].

There are two basic elements of this structure: sandstone slabs that served as the foundation, and andesite blocks that were superstructure. For the former, there are 17 pieces of sandstone defining a flat 6.75 by $38.72 \mathrm{~m}$ area (Fig. 5). The remarkable aspects of the sandstone slabstheir size, their smooth surfaces-have drawn comments for several centuries. In fact, the largest sandstone slabmeasuring 8.12 by 3.86 by $1.2 \mathrm{~m}$ with an estimated weight of 83 tons-has been paced out several times over the centuries, unfailingly educing a corresponding level of

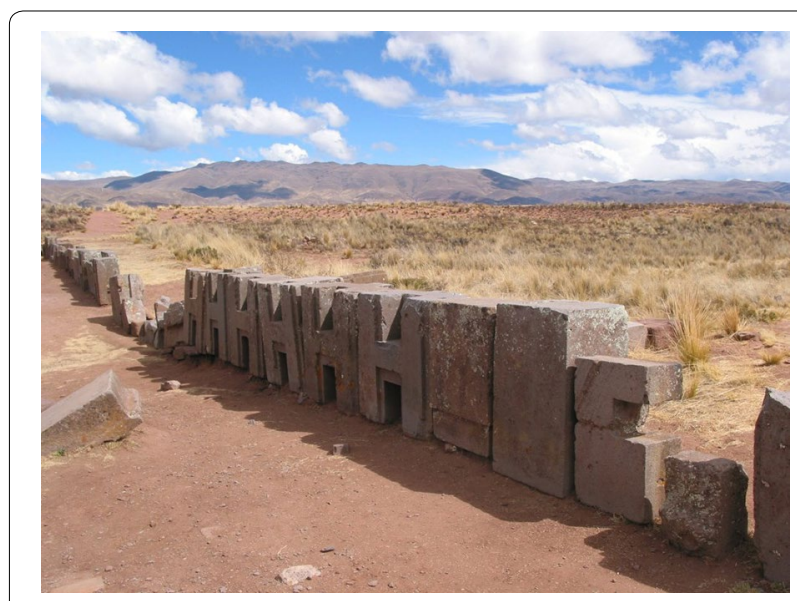

Fig. 6 Andesite blocks

awe and wonderment on the origin and manner of transport of this tremendous stone. The other crucial element of the stone slabs for this study are recessed geometric outlines $^{1}$ that, based on in situ architecture in other locations on the site, were the meeting point or bedding for standing architecture.

The second element of this building features approximately 150 separate pieces of finely cut andesite blocks scattered around these sandstone slabs (Fig. 6); several more can be found further afield across the site and in the local museum. This stonework is characterized by planar surfaces, geometric form, precise edges, and internal right angles. Their sizes range from geometric blocks that can be easily lifted by a person ( 34 by 26 by $14 \mathrm{~cm}$, for an estimated weight of $8.5 \mathrm{~kg}$ ), to the much heralded " $\mathrm{H}$ " stones ( 97 by 99 by $55 \mathrm{~cm}$ for an estimated weight of $600 \mathrm{~kg}$ ), to the iconic gateways carved from a single block measuring slightly under three meters tall, with an estimated weight of $9 \mathrm{t}$ (see Fig. 12). One particular andesite block measures 3.5 by 3.2 by $.64 \mathrm{~m}$ for an estimated weight of 20 metric tons, a tremendous size especially when one considers that the quarry was located on the other side of the lake $[31,32]$.

\section{Principles of Tiwanaku masonry and architecture}

Archaeologists and conservators working on classical period monuments have the advantage of access to a detailed corpus of written documents, graphic representations, and a continent of well-preserved analogs. The reconstruction of a ruined monument, for example the Acropolis in Athens, has its set of challenges, but at least the individual fragments-say, for example, a capital or a

\footnotetext{
${ }^{1}$ These geometric outlines are recessed from $2.5 \mathrm{~cm}$ deep to as little as $5 \mathrm{~mm}$. There are a few that appear to be slightly raised.
} 


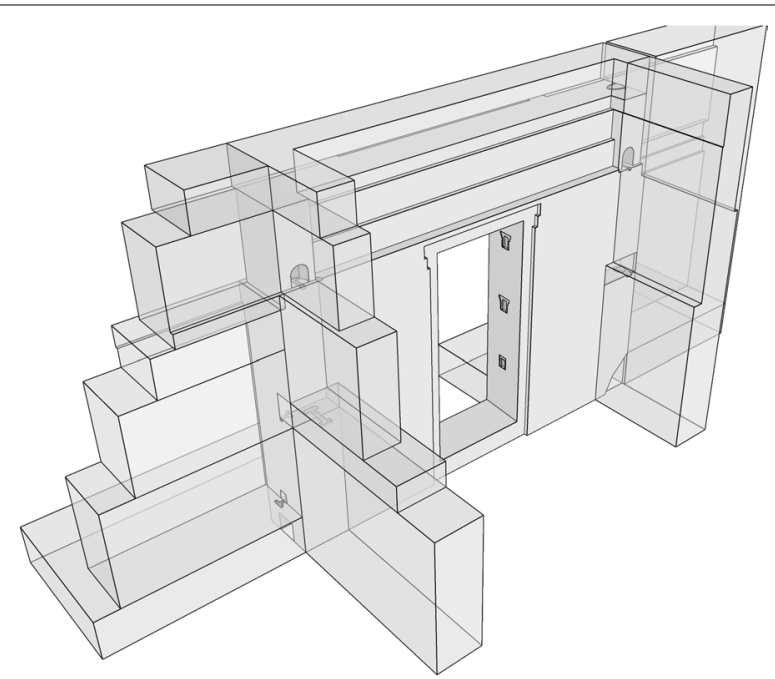

Fig. 7 Virtual reconstruction of a gateway and the projection of the adjoining walls

fragment from the cornice-can be recognized, as would their general position within the larger structure.

Unfortunately, Tiwanaku is firmly embedded within a pre-literate past with little hope of the discovery of indigenous writings on the thoughts and ideas of the builders. There is no standing architecture beyond foundations at the site that can serve as an analog. An unknown number of blocks are missing, and to further complicate matters, the Pumapunku was never completed, which means that we are essentially attempting to reconstruct the unwritten intent in the mind of an architect from over a millennium ago. As a result, reconstructions of this building remain hypothetical if not somewhat speculative (see Sangines 1970 for a series of drawings [33].

Earlier scholars had joined several fragments to form complete pieces, most notably in the case of the gateways $[22,34]$; and the presence of moldings and clamps demonstrated how these gateways were intended to be part of larger architectural context [12] (Fig. 7). Additionally, several generations of observations and studies, on the other hand, have deduced a series of architectural rules that govern the overall form and design of the building. For example, since many of the blocks are perfect replicas of each other, including left and right-hand versions of the same form, repetition and symmetry were part of the design. In addition, the dimensions and proportions of the ubiquitous niche or gateway motif were determined by a mathematical ratio [35].

One unique aspect of Tiwanaku masonry that facilitated reconstruction was that the andesite blocks were also completely dressed and finished before being set in place through the use of hoisting grips that were intricately carved through the andesite. This arduous and challenging task allowed the block to be lowered slowly without damaging the precise friable edge, resulting in a perfect right angle between the block and the floor. Elaborate decorative friezes would span several ashlars; however, unlike in other parts of the world where these finer details would be carved after the blocks were assembled, the Tiwanaku masons completed each ashlar, including the carved frieze, before assembling the structure [12]. Consequently, this unique construction method meant that even if the structure was never actually assembled, a virtual anastylosis, based on reconnecting the frieze and other decorated elements, was indeed possible.

The precision of the mortarless joints allowed a few blocks to be reunited with their likely neighbors [22]. Architect JP Protzen managed to make several more refits, but one of his more significant was his realization that the much-admired carved block known as the "Escritorio del Inca" (Desk of the Inca, henceforth to as Model Stone 1) was an accurate and reduced-scale model (.5774) of a full-scale architectural form (Fig. 8) [35]. Forming an architectural "Rosetta stone," the proportions and relations of the carved ornamentation served to justify joining several andesite blocks to form an architectural composition. Though these and several other blocks have been refit, as of yet, we still lack a view of a complete structure. In particular, the relation between the andesite blocks and the sandstone slabs has still to be established. Protzen cautiously suggests that the architectural composition he reassembled may have flanked either side of a gateway.

\section{Methodology}

Recent technological advances have provided scholars with a host of methods to accurately record volume, surface detail and even color of artifacts and architecture [36]. A series of technology-based grants allowed for a succession of experiments over the years to develop a methodology that addresses the challenge presented by the damaged and fragmentary condition of the ruins [37]. At the time, the intent was not to provide a test of field methods - in effect, Davis [36] provides an extensive review of the costs and potentials of these developing recording technologies and their use in archaeology and heritage management-but rather to find a manner in which the confusion of carved blocks could be recorded and reassembled. For this purpose, not withstanding, we found that laser scanning or photographic digital recording, while producing accurate renderings, required a high degree of work both in the field and in the manual processing back in the lab. In the field, several different perspectives were necessary to capture all sides of an object. In the case of photogrammetry, the photographer 


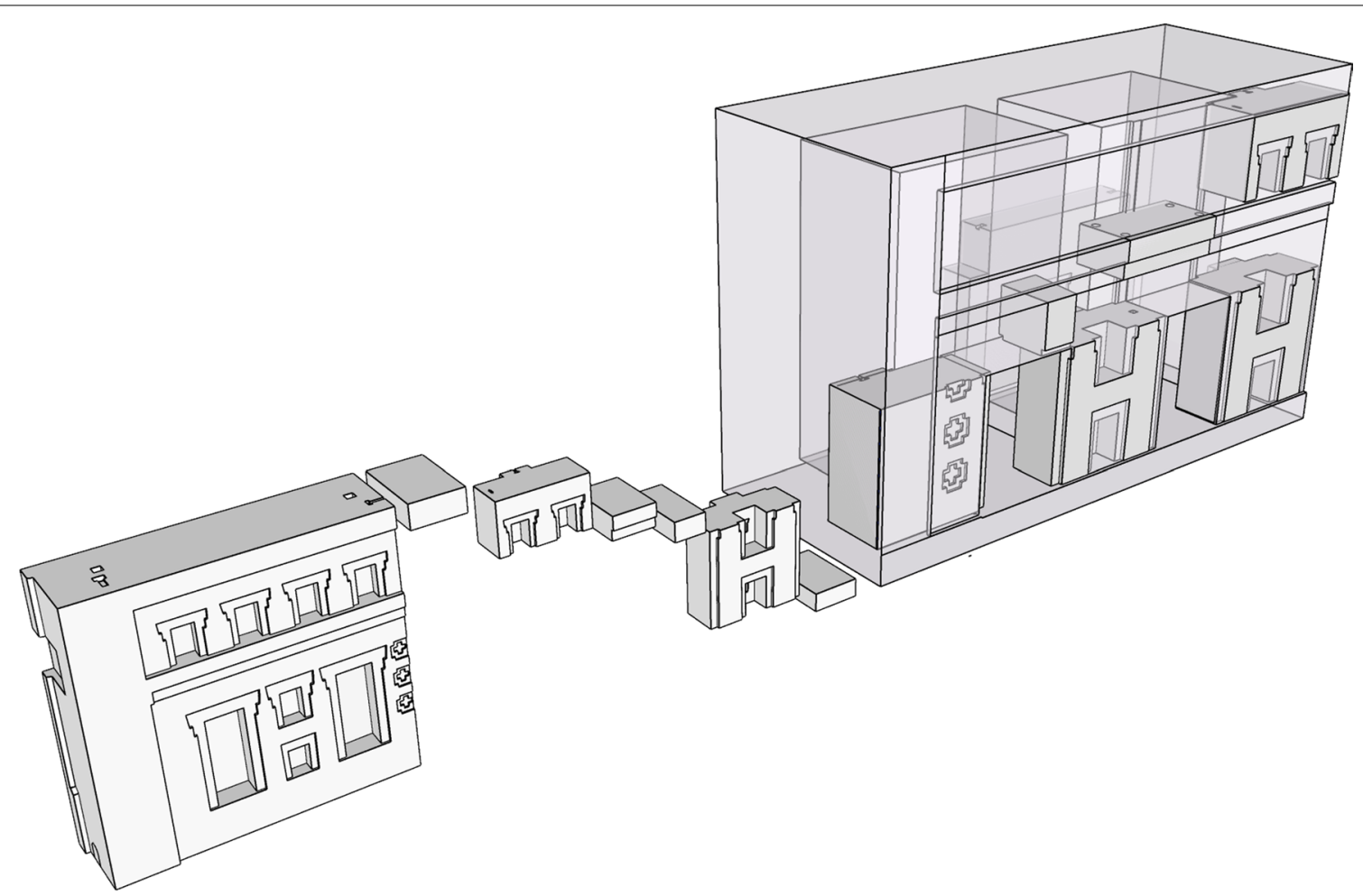

Fig. 8 Model Stone 1 on the left, its individual components in the middle, and its projection into full size architecture with existing andesite blocks

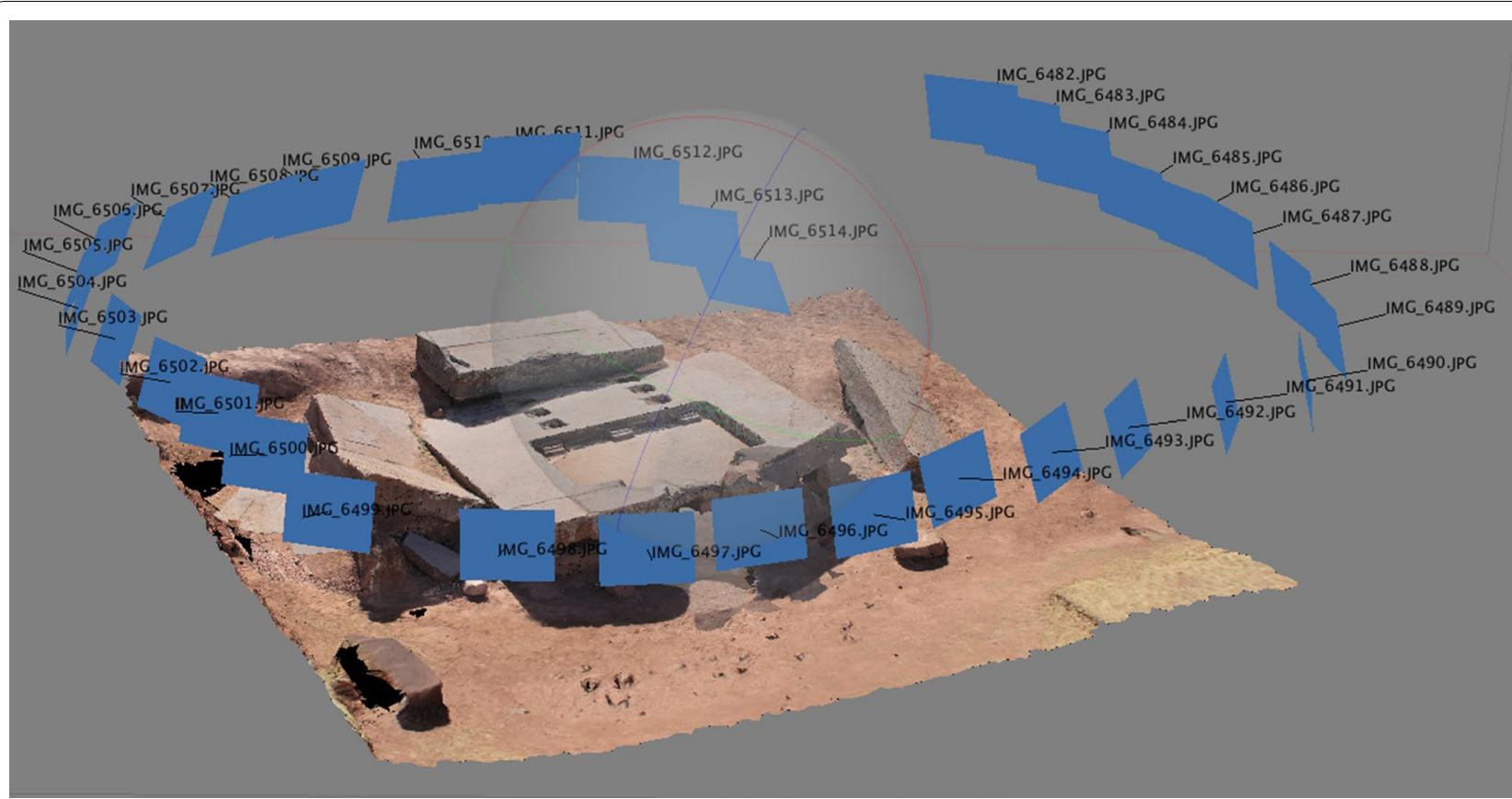

Fig. 9 Location and number of photographs taken for photogrametic reconstruction of a notable carved ashlar known as the "Maqueta" stone 


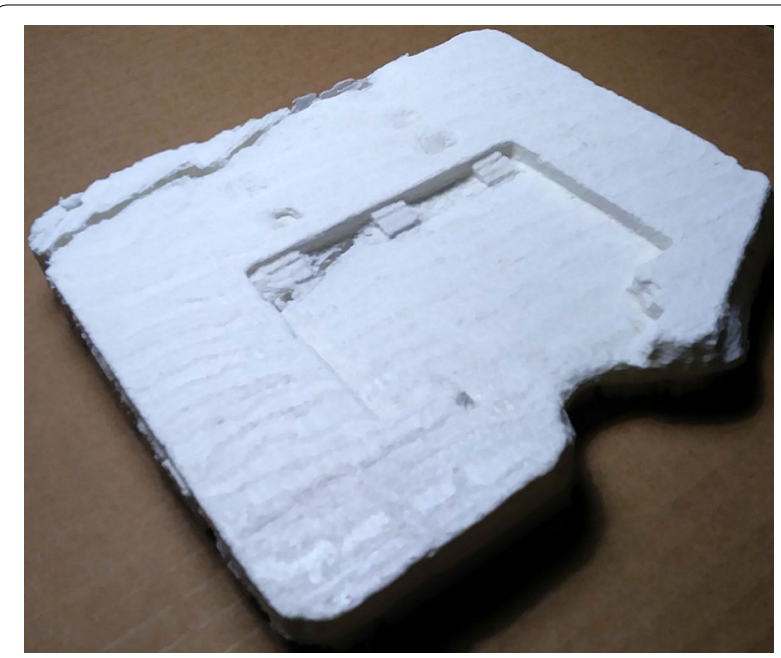

Fig. 10 The "Maqueta" stone 3D printed based on the photogramic model

walking around the object while taking multiple pictures could achieve this (Fig. 9). In the case of laser scanning, the process was somewhat more laborious since the station would have to be broken down, moved to a new location, and set. Thereafter, the different digital images and laser scans of the object would be stitched together in order to form a complete object, and then checked for holes or shadows in the data (areas not visible to the camera or laser scanner). If the holes or shadows were large, an additional field visit would be necessary. Outlying and unnecessary data points, sometimes called 'noise', such as the surrounding terrain and vegetation, needed to be removed. Except under ideal conditions, some degree of manual measurements in the field would still be necessary or at least advisable in order to determine corners and edges that were hidden or buried.

Figure 9 is an example of a photogrammetry test case in near-ideal circumstances. This ashlar, known as the "Maqueta stone" appears to be an elaborate representation of a temple. The conditions for recording were ideal since there was little vegetation or any other obstructions. The total field recording and processing time was estimated to be $4 \mathrm{~h}$. The results, printed on a biodegradable corn-based polyester, known as PLA (polyactic acid), suffered from various ailments, including holes or fragile areas due to the low resolution of the digital image and extraneous data that made the edges appear fuzzy or wavy (Fig. 10). In order for a 3D print to be successful, the model to be printed must be watertight-that is, the surface of the model must not contain any holes (see below).

The hope that these virtual models generated from the laser scans and photogrammetry would be useful as an online archive for the site managers remains, at least at the present moment, unfulfilled since they proved to be too large to download and manipulate with the stakeholders in the rural countryside with limited Internet and computer software and hardware. To the disappointment of the stakeholders, the results were not readily available or comprehensible, and the cost of purchasing and maintaining their own equipment was prohibitive, as was the need for regular input from technicians to specialists who charge dear from their services. Consequently, the extensive laser scans of the ruins and specific sculptures is online and free to download and view but remain an unused resource for the site managers.

Essentially, these methods over-recorded the objects and, for this project, provided unneeded detailed information on surface textures and damage caused by erosion and vandalism. Depending on the number of perspectives necessary to capture the entire object, then, the final file size could be prohibitively large. (The size of the file becomes problematic not because of storage space, but because of the amount of memory required on a computer to work with such a large file). On a practical front, the equipment was expensive, required professional upkeep and a trained operator to record and process the data. Frequently, the equipment was held up in customs for interminable lengths of time; similar equipment was difficult to find in the country and, when it was, the accuracy and usability of the equipment was in serious question. The use of such specialized hardware and software was simply not sustainable in a rural environment of the high Andes, where the harsh climate could easily damage equipment. In these environmental and bureaucratic situations, breakages and technical issues, even when the fix could be relatively easy in the proper circumstances, often meant that the equipment was essentially unusable.

\section{Fieldwork, archives and 3D modeling}

For the purpose of reconstruction, we were primarily interested in the underlying geometry-not the niceties of the damaged and unfinished surfaces. The requisite amount of field data was potentially very small-the lengths of the sides of the blocks and any carved ornamentation. For example, a block could potentially require just three measurements (height, length, and width) in order to accurately model its form. Since these blocks are surprisingly geometric with planar surfaces and precise edges, the original dimensions of the sides of a block with damaged edges could be easily reconstructed using two rulers to project the surviving edges to their original meeting point (Fig. 11). In sum, acquiring the necessary information in the field to model a block could potentially be obtained in minutes. 


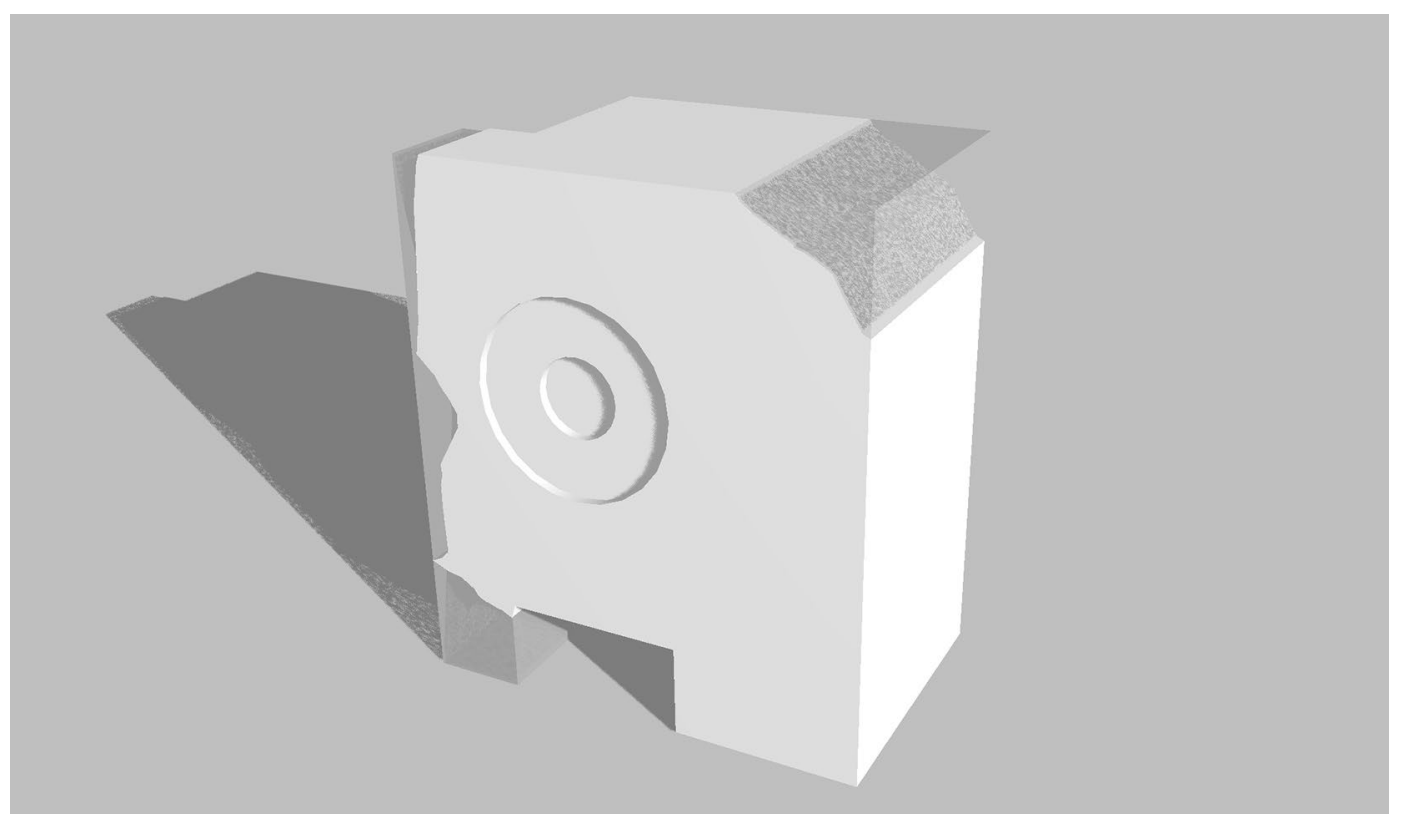

Fig. 11 Projecting the intact edges to reconstruct the location of the missing corner

With the increased prominence and ease of use of 3D printing in the sciences and heritage management [38] and in museum exhibitions designed to engage the senses of the visitor through direct contact with accurate reproductions $[39,40]$, the idea of reconstructing the shattered blocks took on a new life. ${ }^{2}$ Though the sandstone and andesite blocks have been measured on several occasions, in only a few cases was this done with a level of accuracy suitable for the virtual modeling and 3D printing technologies in this research. Consumer 3D printers have a resolution, or margin of error, ranging from $0.025 \mathrm{~mm}$ up to $0.3 \mathrm{~mm}$ depending on the type of 3D printer. This high degree of accuracy in turn necessitates a high degree of accuracy in the models to be printed. Necessary were the original field notes with the detailed measurements not included in their final publications (see Figs. 2, 12). Archival research was necessary to locate the original field notes in various museums around the world. The majority of the ashlars were modeled from the field notes of JP Protzen, who conducted his fieldwork over a number of visits in the early and mid-1990s. The field notes from Leonce Angrand (1848) and Max Uhle (1893) preserved the measurements of several blocks that

\footnotetext{
${ }^{2}$ The idea of making miniatures based on field measurements has been entertained before; in fact, one of the first scholars to visit and publish a scientific treatise on the site (1893) Alfonse Stubel, made wooden models of some of the blocks. Unfortunately, these models, and any notes or findings, were lost in the allied bombing of Leipzig during WWII. Recently, several scholars and aficionados have taken open source material on the blocks to virtually model and print either as a novelty, or to test a specific idea on the fit of a few of the ashlars.
}

had been lost in the last century. Additional ashlars that have recently surfaced were recorded using the method demonstrated by JP Protzen to members of this project.

The use of 3D modeling is nearly commonplace in archaeology, and has the potential to explore phenomenological aspects of a site as 2D plans are extruded and walls and roofs are replaced, given texture, color and even inhabited by avatars [41]. The program AutoCAD, the choice of architects, and an entire suite of rendering programs that allow for realistic textures and forms, is an obvious candidate for the software. In the right hands, AutoCAD is a powerful program with the capacity to accurately model small objects to complex buildings. The downside is that the program can be expensive and has a significant learning curve, especially since many of its functions have to be adapted to the particulars of archaeology [42]. Nevertheless, this program had been previously used to good effect recording and visualizing the results of the excavation of the platform of the Pumapunku $[18,43]$ and even create renderings for phenomenological analysis [44].

However, this type of virtual modeling is best when it comes to extruding a $2 \mathrm{D}$ plan, or a site that has been nearly reduced to its foundations. In this case we were not extruding a ground plan and rendering hypothetical architecture in a realistic manner, but modeling disassociated architectural fragments. Accordingly, this project used the more intuitive and inexpensive (free to 700USD for the full package) 3D modeling software Sketchup. Though originally designed to quickly visualize 3D forms 


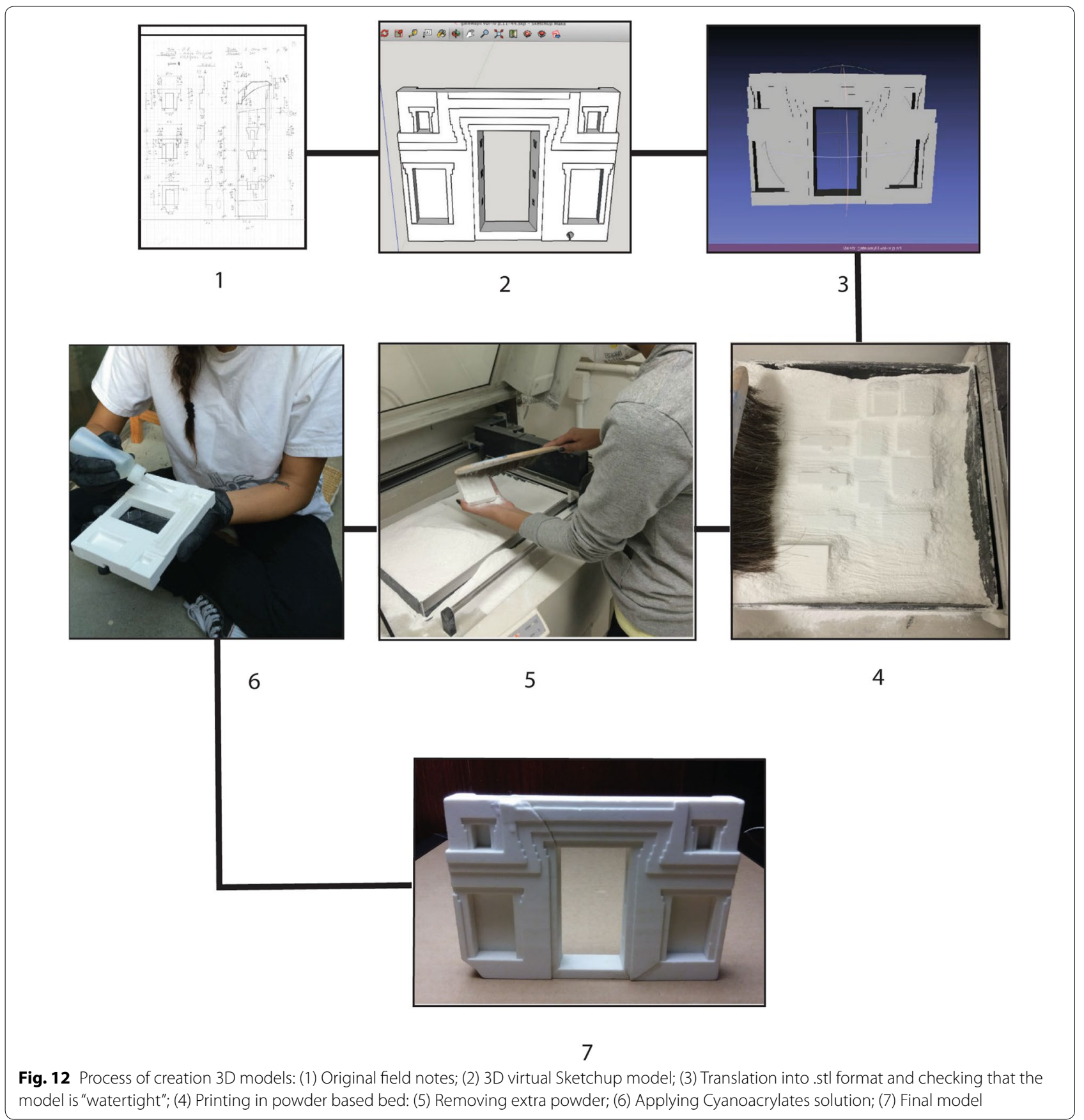

for the purpose of initial conceptualizations of form and volumes, the program does allow for accurate measurements to be entered by mouse and hand. With an hour of training, project members were able to model the more basic fragments; thereafter, the speed of modeling, and the ability to model more complex pieces, rapidly increased.

Recreating every crack and damaged edge proved to be time-consuming and did not contribute to the goal of reconstructing the intended form of the building. Where the evidence of the original form was unequivocal, damaged surfaces and edges were virtually restored to form geometric shapes. In a few cases, virtual and 3D printing anastylosis was performed; as previously mentioned, the fragmented remains of several gateways, scattered around the platform, have been refitted on several different occasions $[22,34]$. Each piece was modeled, then virtually joined with the other fragments to form a 


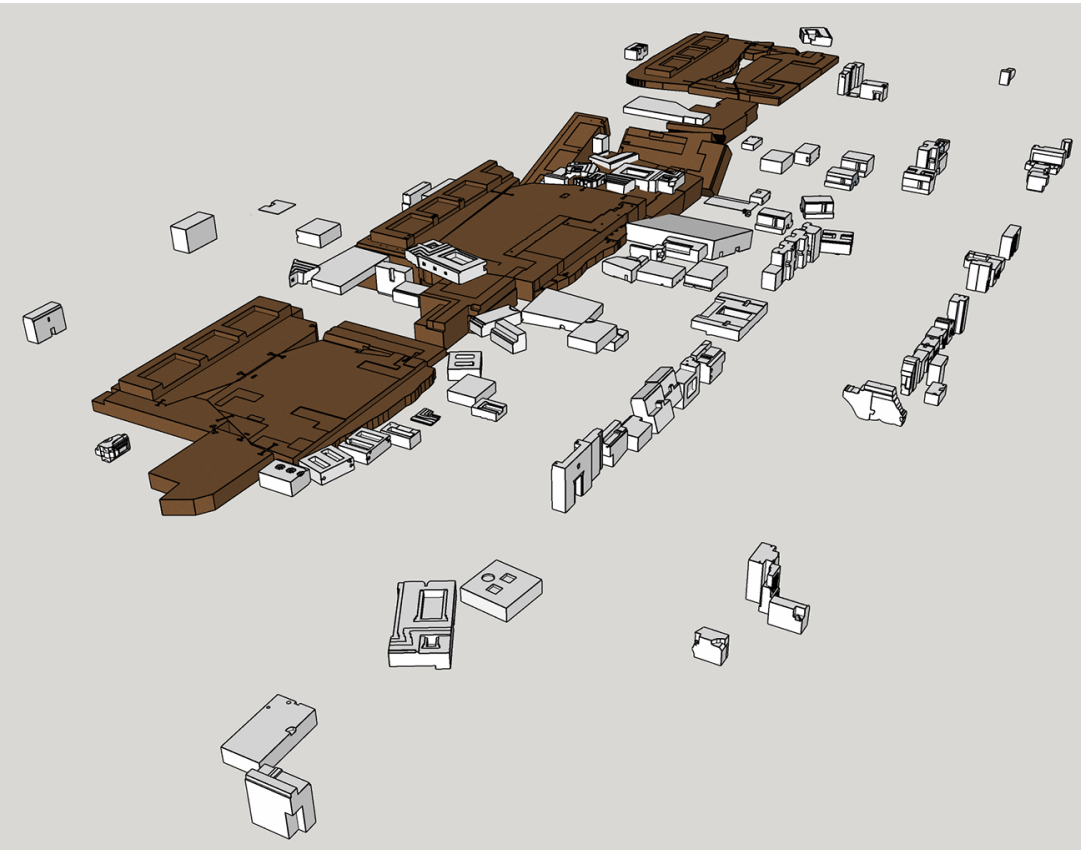

Fig. 13 Virtual models arranged based on the 1848 map (see Fig. 5) and photograph from 1893 (see Fig. 4). Sandstone is in brown

single solid form. Another aspect of the blocks we judiciously choose to virtually modify were clearly unfinished aspects. For example, several of the H blocks seen in Fig. 6 had aspects that were clearly in process of being reduced. Complete examples clearly demonstrated the appearance and form of each side.

In total, 140 pieces of andesite and 17 slabs of sandstone were modeled. The time it would take for a simple unadorned block would be a short as a few minutes; the gateways, the largest, and most complex architectural pieces of this time period require additional time. For example, the gateway in Fig. 12, originally in five pieces, required approximately $5 \mathrm{~h}$ of modeling to restore its virtual form.

Figure 13 is a virtual reconstruction of the appearance of this area of the Pumapunku during the latter half of the nineteenth century, based on in situ authentic remains, Max Uhle's 1893 field notes and photographs, ${ }^{3}$ and Leonce Angrand's 1848 series of drawings [13]. In the last century, several of the blocks were moved around, but most significantly during an unfortunate reconstruction project in 2006. Though by the mid-19th century none of the standing architecture was in place, the effort was made to virtually relocate the ashlars in their

\footnotetext{
3 The original glass plates are stored in the archives of the University of Pennsylvania Museum; the original field notes are in Berlin at the IberoAmerican Institute.
}

earliest known location and position since it may approximate their original place. The Additional file 1 contains the files in sketchup format (.skp) and .stl of the andsite blocks of the Pumapunku, those found in other locations of the site, and the sandstone slabs.

\section{D printing the architecture}

Once these virtual forms were finished, checked for proper dimensions and deemed "watertight," the model was ready for 3D printing. The next step was deciding which of several different types of available material for 3D printing would be most appropriate. (See Coon et al. [45] for a review of the costs and properties of commercially available Rapid Prototyping materials). We used two basic forms of printing: Filament, or Polymer, and power-based. Filament, or Polymer-based printers, use plastic spools of ABS, PLA, and other plastics to make 3D parts. The plastic filament is pushed through a heated

\footnotetext{
${ }^{4} 3 \mathrm{D}$ printers use what are called STL files, or Stereolithographic files generated by CAD software. A 3D model consists of a point cloud, a mesh, and a skin. A point cloud is simply a set of data points in a virtual 3D space-the more points in space, the higher the detail of the model. A wire mesh takes the point cloud and turns it into a polygonal surface by creating triangles out of the point cloud-the more triangles the higher the resolution. The skin of the model turns the triangles into faces, or polygons. The higher the polygon count, the smoother and more detailed the surface of the model. A model is considered watertight if there are no missing polygons and the surface of the model has no holes (or missing triangles).
} 
nozzle $\left(200^{\circ} \mathrm{C}\right)$ and the part is printed layer by layer. The support structure needed for horizontal areas and slopes over $55^{\circ}$. Polymer-based printing material was less expensive; however, they were found to be unsatisfyingly light to handle, and although this was a setting that could be adjusted, the length of time it would take to print would increase exponentially. Typically, an infill, or density, was set at $10 \%$. Furthermore, one could both see and feel the layers of filament, which had the effect of obscuring some of the detail and effecting a distraction. Although the filament printer can print at the same resolution as the plaster printer we settled on (see below), the vertical compression required to ensure that successive layers of filament would adhere properly to those already placed results in a rougher surface than the plaster printer. In addition, the larger pieces had a tendency toward thermal distortion (warping and deformation) during the process of printing due to the temperature distortions that occur during the printing process.

Eventually it was decided to go with the more expensive powder-based printing, using a ZCorp Z310 Rapid Prototyping Printer. A powder-based 3D printer works in much the same way as an inkjet printer. First, a layer of powder, in this case plaster of Paris, is laid down into the print bed. The approximate printing time on powderbased printers is $1 \mathrm{~h}$ per one-inch $(2.54 \mathrm{~cm}) \mathrm{Z}$ height. For example: A stack of ten one half inch thick parts will take around $5-5-1 / 2 \mathrm{~h}$ to print. One hour is needed for drying inside the machine, with another hour needed for the application of CA (cyanoacrylate glue). Since powder printers print in a matrix, the powder material acts as the support structure. This also gives the added advantage of allowing prints to be stacked on top of each other inside the build chamber with a minimum $1 \mathrm{~mm}$ separation.

After that, a print head passes over the bed and deposits a binding agent (much the same as a print head deposits ink on paper) on the designated area. Another layer of plaster powder is deposited, and the print head deposits the binding agent to build the next layer. This particular printer printed at a resolution of 100 microns, or $0.1 \mathrm{~mm}$. The printed objects are initially quite fragile, but a cleaning with an air gun and brush, and an application of a Cyanoacrylates solution (commonly known as "crazy glue"), renders the object solid with the appearance and feel of soapstone or marble. It was important that the Cyanoacrylates solution was applied evenly on all surfaces to prevent warping or cracking. Though slightly more expensive (1.50 USD per cubic inch or $24.6 \mathrm{~cm}^{3}$ ) and labor intensive, the final product preserved the sharp edges, smooth planar surfaces, and other details required to achieve a proper fit. Unlike polymer-based materials, there was no warping or bending of the models due to the heat of the printing process. And, since the parts were being printed in a matrix of plaster powder, there was never any need for support material. ${ }^{5}$ Furthermore, the objects were solid and heavy and thus had a tactile quality familiar to the archaeologist used to manipulating stone and pottery fragments. More than just a personal preference, the objects needed to have a special feel that encouraged handling and that replicated, on a much-reduced level, the stone quality of the actual pieces [34]. The models were reduced, and several sizes were tested; the consensus reached was that $4 \%$ of the actual size provided the right size to easily handle in one hand while preserving details that were so painstakingly modeled. The printed pieces of andesite ranged in size from 15 by $11 \mathrm{~cm}$ for the Gateway of the Sun (original size 3.82 by $2.85 \mathrm{~m}$ ) to 1.36 by 1.04 by $.5 \mathrm{~cm}$ for the smallest piece representing an iconic doorway.

The exception to this printing process was the large sandstone slabs that served as the foundation for the andesite building. Due to its large size ( 6.75 by $38.72 \mathrm{~m}$, or .27 by $1.55 \mathrm{~m}$ when reduced to $4 \%$ ), the entire reconstructed surface was ground from a single piece of medium density fiberboard. In addition to accurately displaying the recessed geometric outlines that were crucial for reuniting the andesite with the sandstone slabs foundations, this piece of fiberboard essentially formed our working surface. The entire collection could be placed at the same time across the fiberboard model of the sandstone slabs (Fig. 14).

An additional advantage of printing the models was the easy detection of errors that might have crept up during the process of recording, modeling or printing the blocks. In $3 \mathrm{D}$ form, differences in size were quick to detect and directed a second look to the notes. In a few cases, virtual models were corrected and printed out a second time.

A trial was even made to print out the missing sections of architecture to compose a complete form. For this, we used a black filament that we could easily distinguish from the white filament or off-white of the plaster pieces. However, these attempts proved to be time-consuming and the pieces unwieldy to move and manipulate. Though the 3D printed models are the imperative theater for tests and trials, the virtual model continues to serve

\footnotetext{
${ }^{5}$ Support material is material that is designed to be easily removed after the print, that acts as a kind of scaffolding to ensure a successful print. For example, if we were to print the letter "F", the $90^{\circ}$ angles would cause the print to fail if there was nothing below it to support the print as it was being constructed. Although the geometry of the vast majority of parts we worked with did not require support material, it is nonetheless extremely advantageous if it can be at all avoided. Ostensibly the support material is designed to be easily removed, however in reality it often proves difficult, and can either damage or otherwise alter the surface of the part that it is connected to.
} 


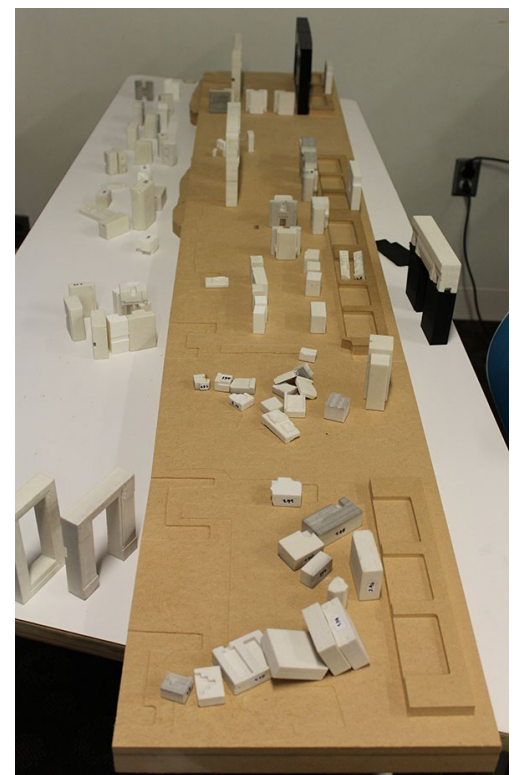

Fig. 14 Printed pieces on the fiberboard representing the sandstone slab foundation

the important purpose of warehousing confirmed refits (see next section below). Since repetition is a characteristic of Tiwanaku architecture, existing pieces could be easily copied and placed; the rest of the structure could be extrapolated along precise angles. Subsequently, the resulting computer models-clearly showing existing pieces and hypothetical sections-could then be virtually manipulated in order to test possible fits with the insets of the sandstone slabs.

\section{D visualization and the mind}

Even when dividing and categorizing the pieces into smaller clusters, the overall appearance of the collection was similar to that of a recently started puzzle or, as commented by nearly every visitor that chanced upon the collection, an elaborate Lego set. This metaphor is appropriate especially since most people entertain themselves with a puzzle until they cross the boundary between a harmless distraction and a maddening obsession. After exhausting what would appear to be all possible matches, leaving and returning a day to the puzzle later often results in a series of quick connections that leaves us with a sense of satisfaction of having "made" something, and a fascination with the ability of our mind to make connections when we are not actively involved in making connections.

For most people, a puzzle is a pleasant pastime; for archaeologists, manipulating small fragments of a larger object is a significant representation of what we do back in the lab. Archaeologists are trained in spatial visualization by spending long periods of trial and error, piecing together objects from bits of broken pottery, stone, and bone. Anecdotes abound among archaeologists of quickly piecing together shattered bits of pottery or realizing that a piece of sculpted stone would fit well in another location of the site. Physical anthropologists are well known for the ability to take a near featureless eroded bone fragment and mentally rotate it to its proper location on the human skeleton. Other professionals, such as masons who work with non-course stone or irregular blocks, also develop an uncanny ability to recall the location of the perfect stone among a disorganized pile in order to fill an oddshaped chink in a wall. Though the actual mental process of insight is not fully understood and beyond the scope of this research, we do know that it can be cultivated both through training and by creating proper setting [46].

For the most part, the process of manipulating the 3D printed pieces involved large periods of time of trying and failing, including applying the proverbial "fools experiment"-attempting impossible combinations with the intent of reaching outside the confines of our paradigms. These often despairingly long periods of time making no tangible progress served to cultivate and increase the chances of "aha" or "eureka" moments, when experts have a sudden and unconscious moment of insight that, while correct, defies explanation even by the author who came to that conclusion [47].

To reach this level of unconscious, but informed, insight, requires the proper condition, and a degree of luck. The attempt to operationalize this often-chaotic process into a methodology was inspired by the field of mathematics, or more specifically and appropriate to this research, geometry which is the more visual aspect of mathematics. Anecdotes abound of mathematicians toiling for long hours only to be suddenly confronted by sudden, and ecstatic, moments of realization, usually when far from actual work. This "fragmentary, informal, intuitive, tentative" [48] process can be roughly divided up into a four stages [49]: (1) Preparation: applying known rules and attempting all possible combinations. Often the most frustrating phase that can potentially last for years; (2) Incubation: the least understood part of the process from the point of view of neuroscience. The unconscious mind is primed with the data from the preparation phase and appears to continue to digest the information as the scholar continues working on other aspects, or even does completely unrelated activity; (3) Illumination: some type of insight, either the solution or an alternative technique to apply to the data, comes into the conscious mind in your classic "eureka" moment; (4) Verification: testing the validity of this insight, which may lead to a heartbreaking and ego-bruising moment when a discovery proves to be false.

For this research, an intimate familiarity with the data was achieved through the measurements in the field, 


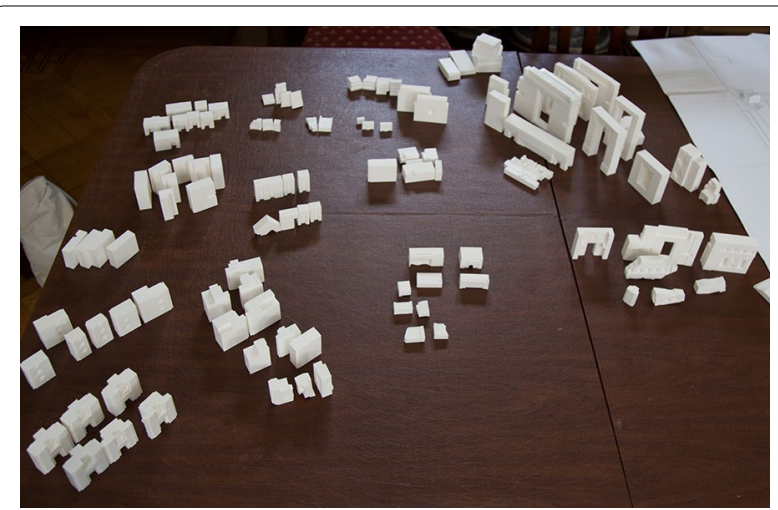

Fig. $153 \mathrm{D}$ pieces divided into categories

and the process of translating 150 years of notes in different languages and varying degrees of legibility into virtual 3D. Though the process was time-consuming, the result was a deep familiarity with each block and its dimensions.

To continue this process of familiarizing oneself with these complex forms, the collection was made easily accessible. The geometry of the piece can be quite complex. This information filled numerous field notebooks from different scholars. The transcription of the measurements to the computer produced orderly rows and columns of numbers that cannot be conceptualized as a whole. An initial attempt to find patterns in these long streams of numbers through the use of specialized algorithms has not yet produced results. The act of printing out these measurements into solid form condenses all this information into a format that can quickly be appreciated. The amount and accessibility of informationboth visual and tactile-are an improvement over the actual unwieldy fragments in the field, or over a constant flipping through of photocopies of raw field notes annotated in another scholar's hand. The entire collection was placed in an open and transited portion of the lab with the intention of encouraging viewing and repeated visitations. The pieces were continually manipulated throughout the day, sometimes even absentmindedly, to the point where the pieces began to develop a patina.

With only a limited understanding of the architectural rules, we started a process of grouping the pieces into categories such size, shape, presence or absence of ornamentation or clamp groove for metal fastening clamps, and thickness (Fig. 15). The expectation was that one of the groupings would reduce the confusing mass of pieces into more manageable subcategories that would lead to a connection or insight. One category that proved useful was height. In the few examples of intact masonry at the site, the Tiwanaku had the unique ability to make perfectly horizontal stone coursing. Based on this analog, ashlars of similar height were more likely to belong to the same course. The pieces of the collection could be quickly divided up by sight and touch, and the trial and error procedure were carried out on pieces of similar height resulting in the union of several more pieces.

At this point, the potential for unconscious associations is high. In effect, the process of refitting can become a somewhat mindless, or perhaps mindful, exercise in handling the pieces over and over again, as their form, size, shape weight and feel became stored in the mind. A potential refit would unexpectedly come at special times of the day, such as first thing in the morning prior to one's mind becoming crowded with the imperatives of the moment, or later in the afternoon after having been doing some activity that required attention but scant creativity.

\section{Case example}

Though more refits were found during this process we lacked anything that could be considered a building, and the relationship between the andesite building and the sandstone slabs continued to elude us. With both the andesite standing architecture and sandstone slabs and geometric outlines or beddings printed out in scale, it would seem that a simple process of trial and error would reunite the andesite blocks with the recessed geometric outlines on the sandstone slabs. However, the only secure connection between an andesite piece and the sandstone slab is on the east side of the slabs where scholars have hypothesized that the gateways were placed at the top of the back-to-back "L" shaped insets (Fig. 16).

Fortunately, one particular refit proved a watershed moment for the reconstruction and serves as an example of the "moment of insight" instant that is facilitated by working with physical $3 \mathrm{D}$ objects as opposed to a 2D plan. As previously noted, Model Stone 1 is not an abstraction, but rather a precise .5774 ratio of an actual structure (or portion of a section). Several more fragments of this reduced scale architecture were identified including a miniature gateway and presented graphically as a single façade (Fig. 17).

The pieces of this reduced scale model were laid out on a working surface in a similar arrangement to the abovementioned graphic, and various attempts were made to identify an appropriate location for such a linear façade. In fact, an early virtual reconstruction modeled and rendered at great effort placed this linear façade along the east side of stone slabs. At one insightful moment, the realization was made that the Model Stone 1 and a miniature gateway met at a right angle (Fig. 18). The other pieces of the former façade were then folded over into the fragmentary sides of four walls of a building. In Fig. 19, 


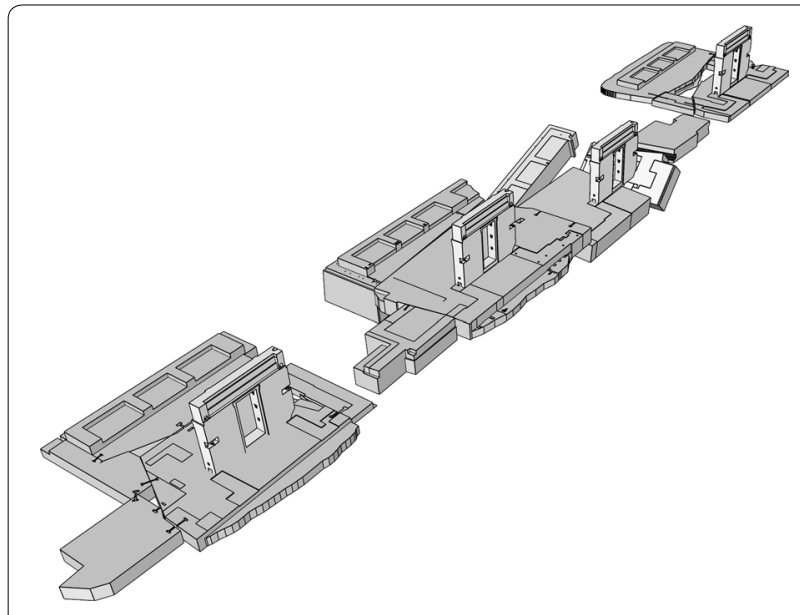

Fig. 16 Likely intended location of the gateways

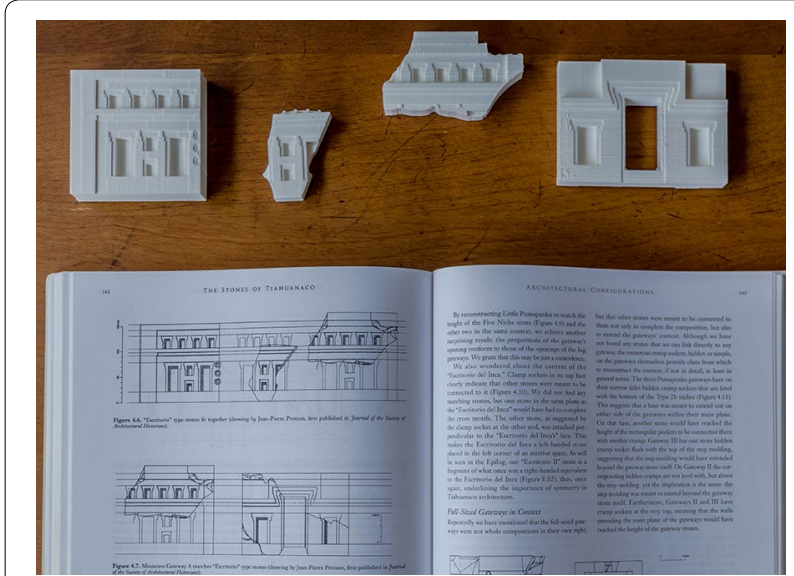

Fig. 17 Model Stone 1 and its associated pieces arranged similar to the graphic 4.6 and 4.7 in Protzen and Nair 2013

all the pieces have been placed into a single hypothetical model and how it may have formed part of a larger architectural context based on moldings, insets, and surfaces. The combination of the architectural model and the moldings on the sandstone slabs was enough to lead to the perceptive partial reconstruction of the northern portion of the andesite building (Fig. 20) and the general layout of the rest of the structure (Fig. 21).

Sufficient remains were reconstructed to depict the form of the Pumapunku andesite building. For the specialist, the form of the building is immediately recognizable as the design of earlier and nearby sites such as Chiripa [50,51] and Pucara on the north side of the Titicaca basin [52] The implication of this realization for our concepts of the development and meaning of the Tiwanaku monuments are far reaching, but beyond the scope of this article. It would suffice to say that by having a confirmed well-preserved analog, we are in a position

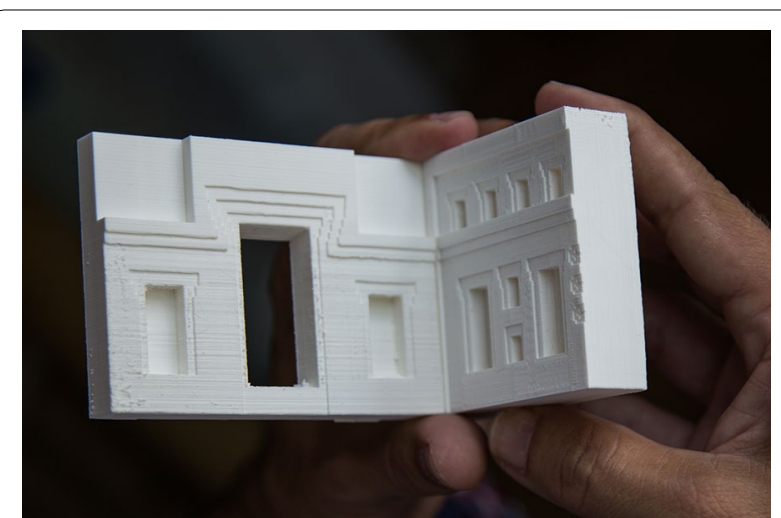

Fig. 18 Perpendicular connection between the miniature gateway and the Model Stone 1

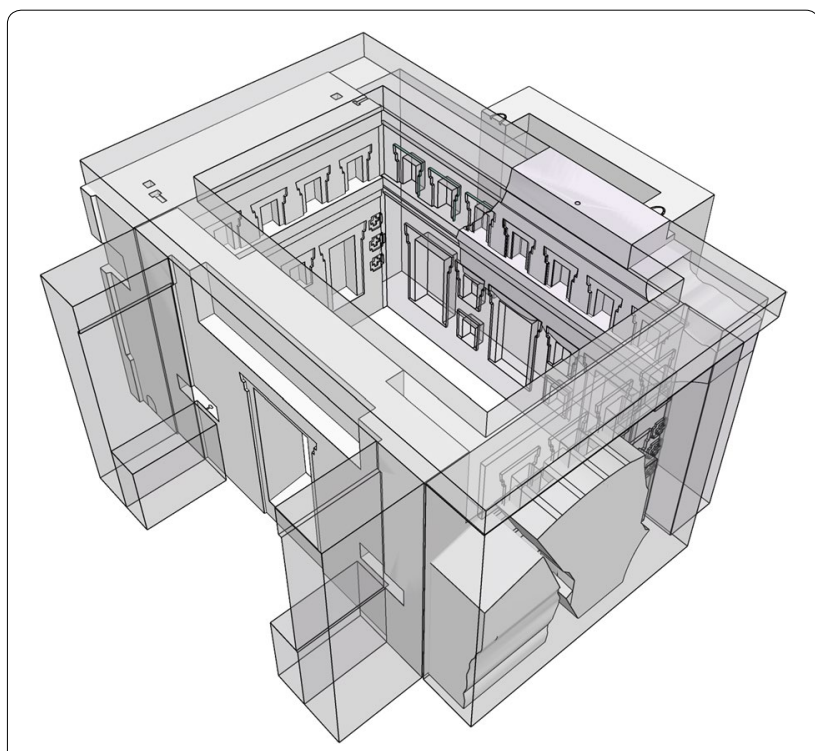

Fig. 19 Virtual model of the model stones in their proper location

to further interpret the fragmented remains of the other monuments at the site. On a minor note, we now have a solid piece of evidence to rebut the mildly irritating persistent claims by ancient alien enthusiasts that hold Pumapunku as a best example of extraterrestrial technology, based in part based on the idea that its form and design has no local precursors [53].

\section{Conclusion}

An enduring hope of archaeologists is that computer automation will free them from the laborious process of refitting broken pieces of ceramics, lithic, and bone. The methodology for digitally recording surfaces and complete objects quickly has been developing rapidly, and now it is feasible to have thousands of objects ranging 


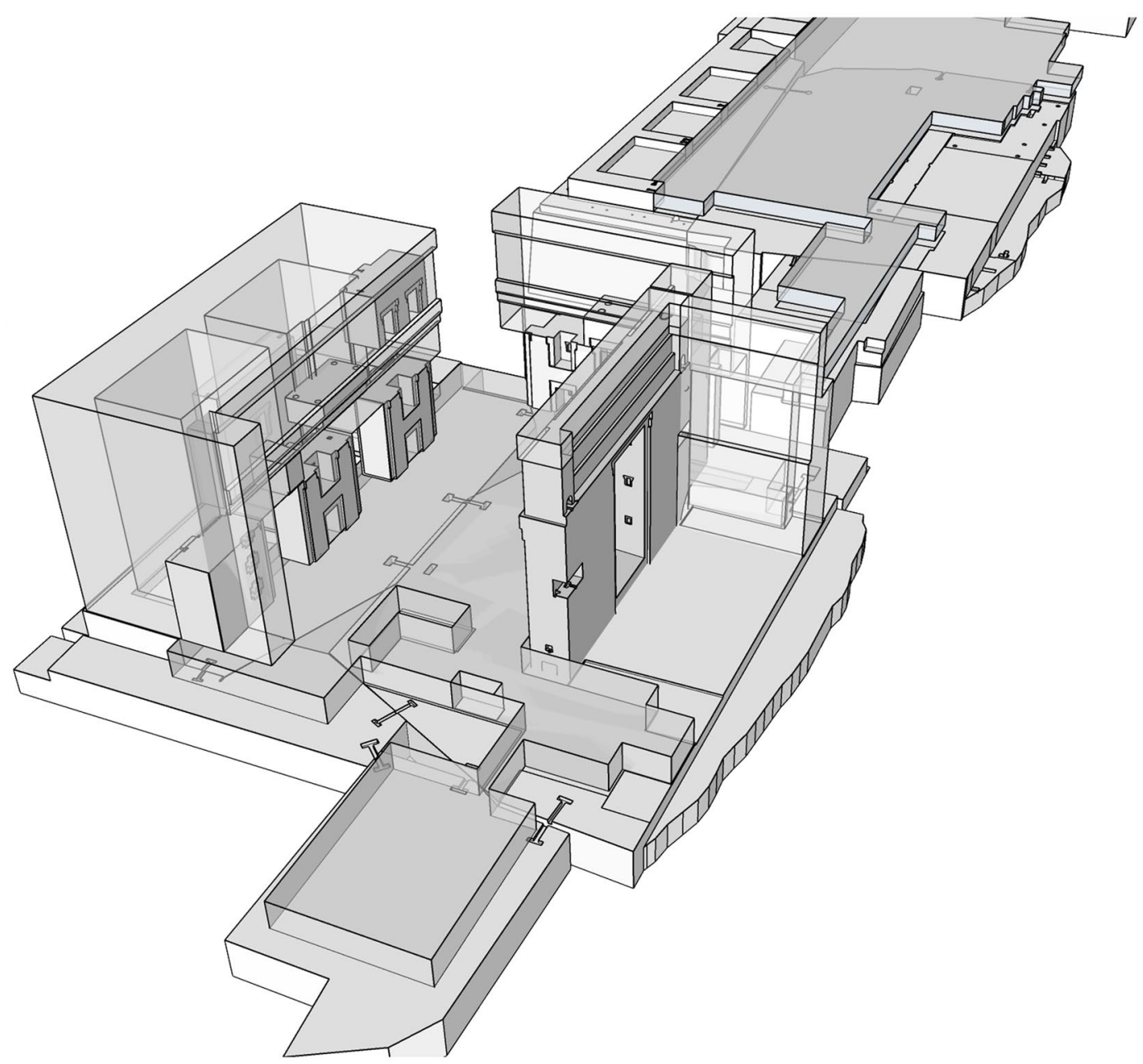

Fig. 20 Virtual reconstruction of the northern portion of the andesite building

from entire landscapes to individual pieces of pottery floating in virtual space on the computer screen. In theory, it would seem that the ability to zoom in and out and manipulate individual objects using the virtual model would be an easy method for testing endless combinations of refits and complete forms; in reality, the technology is not user friendly, and the process of virtually moving and rotating pieces is cumbersome and, perhaps more importantly, non-intuitive. Consequently, the effort to use advanced computer searching and matching algorithms for virtual reassembly remains unfulfilled. Even in the most advanced projects to date, a substantial investment of time is necessary to input the information, verify matches, and account for an entire host of variables not included in the automated process. The result is a series of possible fits that need to be confirmed by the researchers [54]. What a computer may take hours to do (without taking into account the amount of time necessary to create the digital format, not to mention the hours spent writing such a specific piece of software), experienced archaeologists might do in a few moments with the aid of 3D printed objects. There may be a time in the future when ceramics and bone can be tossed on a surface, scanned, and automatically fitted, but until then, the human brain, under the right conditions, continues to be much faster and more efficient than computers when it comes to manipulating and visualizing irregular $3 \mathrm{D}$ forms.

There are those rare people who are able to conceive of three-dimensional forms and manipulate them in their mind. It seems to be an inborn talent, though there is some evidence that it might be developed and cultivated [46]. Rather than create a technology that does a complicated task automatically-the idea of automatic refits based on algorithms and high-powered computing-we used a technology that translated an inconceivable complexity into a format manipulated by hand and effortlessly envisaged. The outcome was the insight that $3 \mathrm{D}$ 


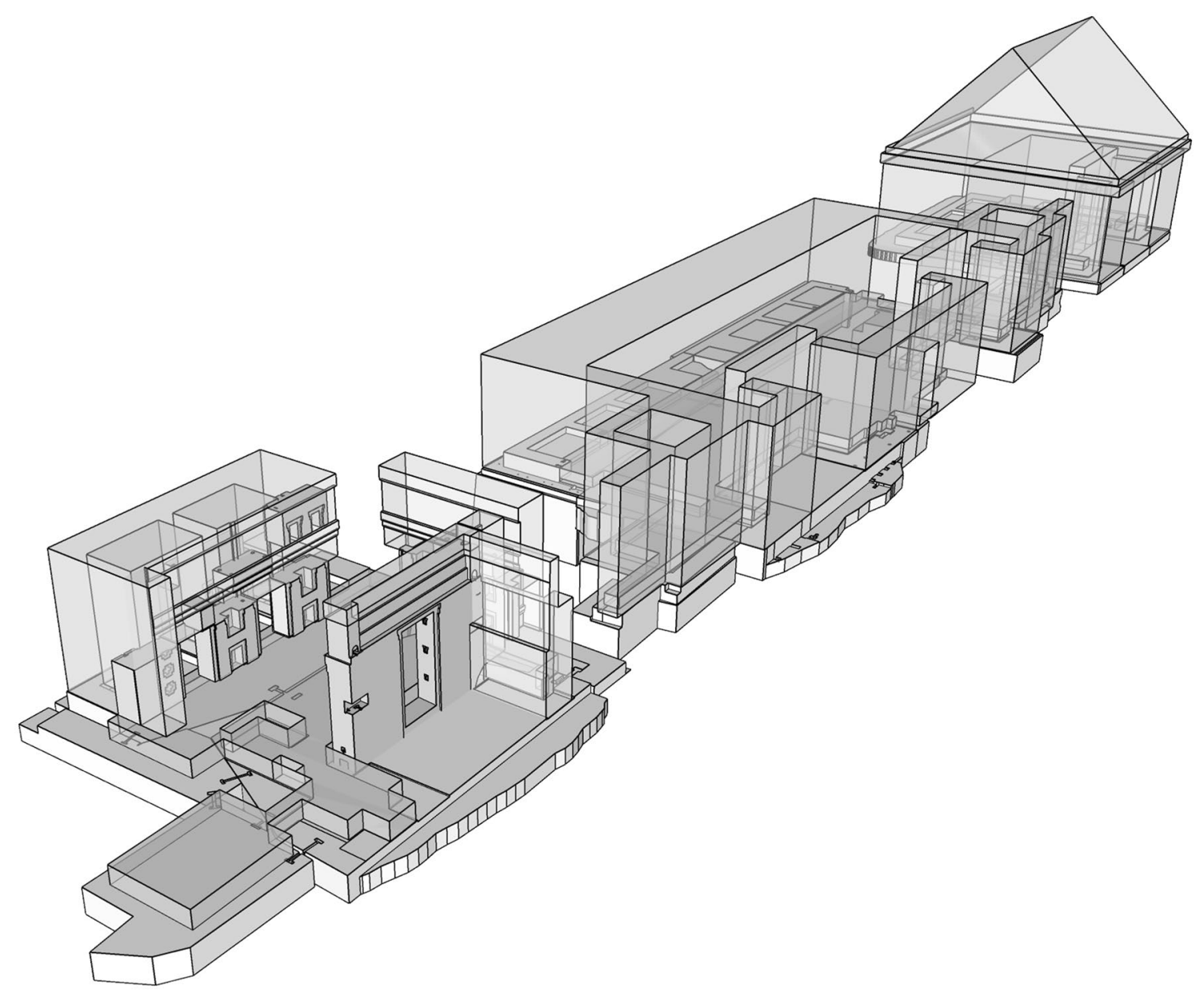

Fig. 21 Virtual reconstruction of the entire andesite building

printing promotes an increase in the quantity of information received by the brain, thus allowing it to do what it does best, which is to determine patterns and make connections. Although this doesn't explain how this mental process actually works, it does take advantage of the fact that one of our hardwired abilities can, with time and training, be enhanced and thus become a decidedly useful tool in particular fields. In other words, we didn't simply automate the process of refitting irregular 3D objects; we actually made it more likely for the unconscious part of the brain to make the necessary connections.

The results for this study attest to the viability of a 3D based methodology to provide the opportunity for the architectural reconstruction of a heavily damaged site. I would expand the term "damage" to include archaeological excavations that are unpublished, or as in Tiwanaku, both unpublished and conducted in a hasty fashion to create read a more monumental experience for tourists. This is an unfortunate reality for many of the major sites around the world and it creates both an unauthentic experience for visitors and prevents scholars from having full access to the necessary data for proper academic and public dissemination. This research demonstrates how one aspect of previous work preserved in archives can be revalued and made compatible with present research design and exhibition needs.

This novel and inexpensive method for archaeological and architectural research requires time, but it is far less expensive than conducting new excavations. Furthermore, there is a minimal investment in hardware or software, and limited specialized training. Field materials consisted of pencil, paper, and tape measure; archival research provided the documents and the necessary information to model on nearly any working laptop using a computer program that is available free of charge for educational purposes. The entire collection, including errors and repeats, was 3D printed and consolidated for $\$ 1200$; we anticipate this cost to decrease in the future. Although less than ideal, using a filament 3D printer would result in a material cost 
of just $\$ 200$, based on our estimates. This documentation and modeling methodology was taught effortlessly to the local archaeologists and recording continues on site. The resulting models can be sent over the Internet and then printed out and added to the model. We recognize that the stonework of the Pumapunku is exceptional and lends itself well to this methodology owing to the geometry of the ashlars and the precision of their mortarless joints. Consequently, the application of this methodology in other situations might require modification.

\section{Online archive}

All too often researchers are not allowed to have direct contact with the architecture or to physically disturb the structures. In the case of the Pumapunku, several of the ashlars show the markings of previous measurements that were executed carelessly with metal tools; in fact, the area immediately around the blocks has been excavated on more than one occasion in order to locate and measure buried corners and foundations. Fortunately, the online collection provides an accessible resource, both virtual and ready to print, while protecting the architecture and reducing the need to travel to the site. This online resource addresses the recent call to engage the public-or "citizen scholars"-to use one popular term, in solving specific problems by using open source material [55]. Even a casual search on the Internet for "Pumapunku" reveals thousands of sites and references, although mostly refer to pseudoscience theories on lost continents and extraterrestrial interventions. Regardless of motivation or intent, the placement of the shape files online and the easy accessibility of 3D printers mean that scholars and amateurs can print out their own complete collection and find potential refits.

Archaeological sites with a long history of research often have a corpus of incompatible and underutilized documentation and, as a result, research is not cumulative. Tiwanaku is particularly affected by this condition and is caught in a cycle of same "discovery" being made by every generation. The stones of the Pumapunku-in particular the sandstone slabs-have been measured, drawn, and published many times over. The final publication of these graphics result by necessity in a muchreduced version of a larger map that lacks the requisite measurements to test and replicate the documentation. The online archive preserves all the measurements of the ashlars, and while a future scholar may want to revisit the primary material, the detailed measurements of the architecture is maintained and accessible to them.

\section{Diverse stakeholders and community involvement}

What is lamentable about the reconstruction efforts for archaeological sites in Bolivia-and also in South America in general-is the lack of open discussion among experts and invested locals in the manner and extent of preservation and reconstruction. Similar to other locations in the Americas where colonization and forced conversion created a break between the present inhabitants and their archaeological heritage [56], the local people tend to view the value of the site as a place of temporary employment and, up until recently, a convenient quarry (thought this is not always the case. See Liebman 2012 for an example from the American southwest [57]). This was the case with the 2006 project at the Pumapunku, where the archaeologists were presented with an impossible mandate from an interim president of the Republic to "fix" the ruins. Under intense political pressure to produce results and start spending the funds for local labor, the site was heavily altered and several blocks were reset in a manner the local archaeologists knew was unsupported by the archaeological evidence. This research is not the complete solution to bad government and an apathetic public, but it a comprehensible media where various stakeholders can discuss prior to any irrevocable changes to the site. The use of models is far more comprehensible and more appropriate in this case, in view of the fact that the peoples in the Andes have a long history in the use models to design, plan, and even conceptualize entire landscapes [58]. This use of engaging models can provide a media for the diverse stakeholders-from experts to indigenous leaders - to openly discuss the extent of the interventions, their relationship to the archaeological data, international convention of conservation, and the effect these issues will have on the visitor experience.

\section{Additional file}

Additional file 1. 3D models of (1) Andesite blocks from the Pumapunku, (2) Sandstone slabs from the Pumapunku, (3) Andesite blocks from locations other than within the boundaries of the Pumapunku monument, and (4) Gateways at the Pumapunku and other areas of the ruins in .skp and stl format.

\section{Authors' contributions}

The author read and approved the final manuscript.

\section{Acknowledgements}

This research project was completely under an agreement between the University of Pennsylvania (and thereafter the University of California, Los Angeles) and the National Institute of Archaeology of Bolivia. The Director of Archaeology was Javier Escalante. The student team that processed, and visualized and printed the data was Guillermo Campos, Agnes Aiko Horimoto and 
Prudence Tang. Printing was carried out by Philip Soderlin at the School of Art and Architecture at UCLA and by Doug Daniels at the Young Research Library at UCLA. Dr. Alyssa Loorya photographed the 3D models for this publication.

\section{Competing interests}

The author declares no competing interests.

\section{Availability of data and materials}

The 3D models in .skp and.stl format are available in the Supplementary Information and available for download. (1) Andesite blocks from the Pumapunku, (2) Sandstone slabs from the Pumapunku, (3) Andesite blocks from locations other than within the boundaries of the Pumapunku monument and (4) Gateways at the Pumapunku and other areas of the ruins.

\section{Funding}

This aspect of the research was carried out with a private donation from Kurt Bost and the Coca Cola Corporation.

\section{Publisher's Note}

Springer Nature remains neutral with regard to jurisdictional claims in published maps and institutional affiliations.

Received: 15 January 2018 Accepted: 15 November 2018

Published online: 13 December 2018

\section{References}

1. Tihuanacu. Buenos Aires: Emecé editores, s. a; 1943. p.151 (Colección Buen aire. [no. 28]).

2. Conklin WJ, Moseley ME. The pattern of art and power in the early intermediate period. In: Keatinge R, editor. Peruvian prehistory. Cambridge: Cambridge University Press; 1988. p. 145-63.

3. Chavez K. The significance of Chiripa in Lake Titicaca basin development. Expedition. 1988;30:17-26.

4. Vranich A. Visions of Tiwanaku. Los Angeles: The Cotsen Institute of Archaeology Press; 2013. p. 1-9.

5. de Ayala FGP. El primer nueva corónica y buen gobierno. 1st ed. México: D.F: Siglo Veintiuno; 1980.

6. Ponce Sanginés C. Tiwanaku y su fascinante desarrollo cultural: Ensayo De Síntesis Arqueológica. La Paz: Producciones CIMA; 2001.

7. Janusek JW. Incipient urbanism at the early Andean center of Khonkho Wankane, Bolivia. J Field Archaeol. 2015;40(2):127-43.

8. Gasparini G, Margolies L. Arquitectura Inka. Armitano; 1976.

9. Himpele JD. University of California (System), University Extension, Center for Media and Independent Learning. Taypi Kala: six visions of Tiwanaku. Berkeley: University of California Extension Center for Media and Independent Learning; 1994.

10. Sammells CA. Touristic narratives and historical networks: politics and authority in Tiwanaku, Bolivia. PhD Dissertation, Department of Anthropology, University of Chicago; 2009.

11. Vranich A. Coping with Chaos. Archaeology. 2003;56(3):62-6.

12. Protzen J-P, Nair S. The stones of Tiahuanaco: a study of architecture and construction (monograph). Los Angeles: The Cotsen Institute of Archaeology Press, University of California; 2013.

13. Prümers H. Las Ruinas de Tiahuanaco en el año 1848 - Dibujos y notas de Léonce Angrand./Die Ruinen von Tiahuanaco im Jahre 1848 - Zeichnungen und Notizen von Léonce Angrand. Beitr Zur Allg Vgl Archäol 13 385-478 Mainz. 1993. https://www.academia.edu/1242804/Las_ Ruinas_de_Tiahuanaco_en_el_a\%C3\%B1o_1848_Dibujos_y_Notas_ de_L\%C3\%A9once_Angrand._Die_Ruinen_von_Tiahuanaco_im_Jahre _1848_-_Zeichnungen_und_Notizen_von_L\%C3\%A9once_Angrand. Accessed 11 Jan 2018.

14. Protzen J-P, Nair S. Who taught the Inca stonemasons their skills? A comparison of Tiahuanaco and Inca cut-stone masonry. J Soc Archit Hist. 1997;56(2):146-67.

15. Cordero M. Informe preliminar acerca de las excavaciones en Pumapunku. La Paz: Instituto Nacional de Arqueología de Bolivia; 1978.
16. Estévez C J. Excavaciones arqueológicas en el sector sur del templo de Pumapunku, Tiwanaku (Informe de los trabajos de campo de la gestión de 1989). 1989.

17. Escalante Moscoso JF. Arquitectura prehispánica en los Andes Bolivianos. 1993.

18. Vranich A. Interpreting the meaning of ritual spaces: the temple complex of Pumapunku, Tiwanaku, Bolivia. Dissertation Abstracts International. University of Pennsylvania, 1999.

19. Vranich A. Construction and reconstruction of ritual space at Tiwanaku, Bolivia (A.D. 500-1000). J Field Archaeol. 2006; 31(2):121-36.

20. Cobo B. Inca religion and customs. Austin: University of Texas Press; 1997.

21. de la Vega G, Livermore HV, Toynbee A. Royal commentaries of the Incas, and general history of Peru. Austin: University of Texas Press; 1987.

22. Stiibel A, Uhle M. Die ruinenstaette von Tiahuanaco im Hochlande des alten Peru: Eine kultui;geschichtliche Studie auf Grund selbstaendi ger Aufnahmen. Breslau: Verlag von C. T. Wiskott; 1892.

23. Mercado de Penalosa P. Relacion de la Provinciade Pacajes. Relacion Geografia de Indias. 2nd ed. Madrid: Ministro de Fomento; 1885.

24. de Lizárraga R, Ballesteros I. Descripción del Perú, Tucumán, Río de la Plata y Chile. Madrid: Dastin; 2002.

25. Alvarez A. A través de la América del Sur. Madrid: Historia 16; 1987.

26. de Laporte Castelnau F. Antiquités des Incas et autres peuples anciens: recueillies pendant l'expédition dans les parties centrales de l'Amerique du Sud de Rio de Janeiro à Lima, et de Lima au Para: exécutée par ordre du gouvernement français pendant les années 1843 à 1847. Paris: Bertrand; 1854.

27. D’Orbigny A. Viaje a la América Meridional. Buenos Aires: Editorial Futuro; 1945.

28. Pentland JB, Fifer JV. Report on Bolivia, 1827. London: Offices of the Royal Historical Society; 1974.

29. Squier EG, Willey GR. Peru: incidents of travel and exploration in the land of the Incas. New York: AMS Press Inc.; 1973.

30. Wiener C, Rivera Martínez E, Riviale P. Perú y Bolivia. Relato de viaje. Lima: Institut français d'études andines; 2015.

31. Vranich A, Harmon P, Knutson C. Reed boats and experimental archaeology on Lake Titicaca. Expedition. 2005;47(2):20-7.

32. Knutson C. The, "Tired Stones" of Lake Titicaca. Expedition. 2007:49(1):46-8.

33. Ponce Sanginés $C$. Acerca de la procedencia del material lítico de los monumentos de Tiwanaku: I. Examen Arqueológico. II. Estudio Geológico Petrográfico. Bolivia: Academia Nacional de Ciencias de Bolivia Publicación; 1970

34. Posnansky A. Tihuanacu, the cradle of American man. New York: J.J. Augustin; 1945.

35. Protzen J-P, Nair SE. On reconstructing Tiwanaku architecture. J Soc Archit Hist. 2000;59(3):358-71.

36. Davis A, Belton D, Helmholz P, Bourke P, McDonald J. Pilbara rock art: laser scanning, photogrammetry and 3D photographic reconstruction as heritage management tools. Herit Sci. 2017;4(5):25.

37. Cothren J, Ernenwein E, Vranich A, Goodmaster C. Fusion of three-dimensional data at Tiwanaku: an approach to spatial data integration. Road Reconstr Past Comput Appl Quant Methods Archaeol CAA Proc 36th Int Conf Bp April 2-6; 2008. https://www.academia.edu/11206439/Fusio n_of_Three-Dimensional_Data_at_Tiwanaku_An_Approach_to_Spati al_Data_Integration. Accessed 18 Mar 2017.

38. Balletti C, Ballarin M, Guerra F. 3D printing: state of the art and future perspectives. J Cult Herit. 2017;1(26):172-82.

39. $3 \mathrm{D}$ printing allows the blind to experience famous artwork. pastemagazine.com. https://www.pastemagazine.com/articles/2015/04/3d-print ing-allows-the-blind-to-experience-famous.html. Accessed 16 May 2018.

40. Williams TL. More than just a novelty? Museum visitor interactions with 3D printed artifacts, Thesis. 2017. https://digital.lib.washington.edu:443/ researchworks/handle/1773/39772. Accessed 16 May 2018.

41. Rua H, Alvito P. Living the past: 3D models, virtual reality and game engines as tools for supporting archaeology and the reconstruction of cultural heritage - the case-study of the Roman villa of Casal de Freiria. J Archaeol Sci. 2011;38(12):3296-308.

42. CSA Home Page. http://www.csanet.org/. Accessed Jan 122018.

43. Vranich $A$. The construction and reconstruction of ritual space at Tiwanaku, Bolivia (A.D. 500-1000). J Field Archaeol. 2006;31(2):121-36. 
44. Vranich A. Seeing what is not there: reconstructing the monumental experience. BAR Int Ser 1035. 2002. https://www.academia.edu/9286659/ Seeing_What_is_Not_There_Reconstructing_the_Monumental_Exper ience. Accessed 18 Mar 2017.

45. Coon C, Pretzel B, Lomax T, Strlič M. Preserving rapid prototypes: a review. Herit Sci. 2016;22(4):40.

46. Sorby SA, Manner KJ, Baartmans BG. 3-D visualization for engineering graphics. Upper Saddle River: Prentice Hall; 1998.

47. Gladwell M. Blink: the power of thinking without thinking. New York: Back Bay Books; 2014.

48. Hersh Reuben. What is math, really. New York: Oxford University Press; 1997.

49. Littlewood JE. Littlewood's Miscellany. Revised edition. Bollobás B, editor. Cambridge, New York: Cambridge University Press; 1986.

50. Hastorf CA. Community with the ancestors: ceremonies and social memory in the Middle Formative at Chiripa, Bolivia. J Anthropol Archaeol. 2003;22(4):305-32.

51. Bandy MS. Fissioning, scalar stress, and social evolution in early village societies. Am Anthropol. 2004;106(2):322-33.
52. Klarich EA. From monumental to the Mundane: defining early leadership strategies at late formative Pukara, Peru. Santa Barbara: University of California; 2005.

53. Watch the mystery of Puma Punku full episode-ancient aliens. http:// www.history.com/shows/ancient-aliens/season-4/episode-6. Accessed 16 May 2018.

54. Koller D, Levoy M. Computer aided reconstruction and new matches in the forma Urbis Romae. Bullettino Della Commissione Archeologica Comunale di Roma, Supplementi 15; 2006. p. 103-125.

55. About $\mathrm{GX}^{\circ} \mid$ About Us | GlobalXplorer ${ }^{\circ}$. https://www.globalxplorer.org/ about/\#bio. Accessed 19 May 2018.

56. Parks S, McAnany PA, Murata S. The conservation of Maya cultural heritage: searching for solutions in a troubled region. J Field Archaeol. 2006:31(4):425-32.

57. Liebmann M. Revolt: an archaeological history of Pueblo resistance and revitalization in 17th century New Mexico. 1st ed. Tucson: University of Arizona Press; 2014. p. 328.

58. Pillsbury J, Sarro PJ, Doyle JA, Wiersema JB. Design for eternity: architectural models from the ancient Americas. 2015.

\section{Submit your manuscript to a SpringerOpen ${ }^{\circ}$ journal and benefit from:}

- Convenient online submission

- Rigorous peer review

- Open access: articles freely available online

- High visibility within the field

- Retaining the copyright to your article

Submit your next manuscript at $\boldsymbol{\nabla}$ springeropen.com 